\title{
Synthesis and Exploitation of the Biological Profile of Novel Guanidino Xylofuranose Derivatives
}

\author{
Andreia Fortuna, ${ }^{\mathrm{a}, \mathrm{b}}$ Rita Gonçalves-Pereira, ${ }^{\mathrm{a}}$ Paulo J. Costa, ${ }^{\mathrm{b}}$ Radek Jorda, ${ }^{\mathrm{c}}$ \\ Veronika Vojáčková, ${ }^{\mathrm{c}}$ Niels V. Heise,${ }^{\mathrm{d}}$ René Csuk, ${ }^{\mathrm{d}} \mathrm{M}$. Conceição Oliveira, ${ }^{\mathrm{e}}$ and \\ Nuno M. Xavier ${ }^{\mathrm{a}, *}$ \\ ${ }^{a}$ Centro de Química Estrutural, Faculdade de Ciências, Universidade de Lisboa, \\ Ed. C8, $5^{\circ}$ Piso, Campo Grande, 1749-016 Lisboa, Portugal \\ ${ }^{b}$ BioISI - Biosystems \& Integrative Sciences Institute, Faculdade de Ciências, \\ Universidade de Lisboa, Ed. C8, Campo Grande, 1749-016 Lisboa, Portugal \\ ${ }^{\mathrm{c}}$ Department of Experimental Biology, Palacky University, Faculty of Science, \\ Šlechtitelu 27, 78371 Olomouc, Czech Republic \\ ${ }^{d}$ Bereich Organische Chemie, Martin-Luther-Universität Halle-Wittenberg, Kurt- \\ Mothes-Str. 2, D-06120 Halle (Saale), Germany \\ ${ }^{e}$ Centro de Química Estrutural, Instituto Superior Técnico, Universidade de Lisboa, \\ Av. Rovisco Pais, 1049-001 Lisboa, Portugal
}

*Correspondence: nmxavier@fc.ul.pt

\begin{abstract}
The synthesis of novel guanidino sugars as potential mimetics of nucleosides and their biological evaluation is described. 5-Guanidino xylofuranoses containing different $O$ substituents at C-3, including saturated/unsaturated hydrocarbon chains and aromaticcontaining moieties, were accessed from 5-azido xylofuranose precursors through reduction followed by guanidinylation of the obtained amines with $N, N^{\prime}$-bis (tertbutoxycarbonyl)- $N{ }^{\prime \prime}$-triflylguanidine. A 5-azido 3-O-methyl-branched $N$-benzyltriazole isonucleoside was converted into the corresponding 5-guanidino-containing isonucleoside, whose structure includes both the guanidine and triazole moieties as nucleobase-like motifs connected to the xylofuranose template. In alternative, this structurally new type of compound was synthesized via cycloaddition between a 5guanidino-3-O-propargyl xylofuranose derivative and benzyl azide in the presence of a CuI/Amberlyst A-21 catalytic system, along with the 5-iodotriazole derivative as a secondary product, which, in turn was the sole product when using equimolar $\mathrm{CuI}$ and a catalytic amount of 4-dimethylaminopyridine. A guanidinomethyltriazole 3'-O-dodecyl xylofuranos-5'-yl isonucleoside, which comprise a novel isonucleosidic framework having a guanidine system appended on the sugar-linked triazole motif, was obtained from the related aminomethyltriazole 5'-isonucleoside via guanidinylation. Bioactivity screening revealed 2 compounds as selective inhibitors of acetylcholinesterase (AChE), namely the guanidinomethyltriazole derivative, with moderate inhibition $\left(K_{\mathrm{i}}=22.87 \mu \mathrm{M}\right)$
\end{abstract}


and the 3-O-dodecyl ( $N$-Boc)guanidino xylofuranose, which was the most active compound $\left(K_{\mathrm{i}}=7.49 \mu \mathrm{M}\right)$ acting as a non-competitive inhibitor. The latter also displayed moderate antiproliferative effects in chronic myeloid leukemia $\left(\mathrm{K} 562, \mathrm{GI}_{50}=31.02 \mu \mathrm{M}\right)$ and in breast cancer $\left(\mathrm{MCF}-7, \mathrm{GI}_{50}=26.89 \mu \mathrm{M}\right)$ cells. The aminomethyltriazole 5'isonucleoside was the most potent molecule with single-digit micromolar GI50 values against both cells $\left(\mathrm{GI}_{50}=6.33 \mu \mathrm{M}\right.$ and $\left.8.45 \mu \mathrm{M}\right)$, similar to that of the standard drug 5fluorouracil against MCF-7 cells.

Keywords: guanidino sugars; isonucleosides; guanidinylation: antiproliferative activity; cholinesterase inhibitors

\section{Introduction}

The guanidine moiety has attracted significant interest in medicinal chemistry, due to its presence in several bioactive natural and synthetic compounds of pharmaceutical potential [1-3]. The stability of this functionality, its basic nature, the ability for cation- $\pi$ [4] and hydrogen bond interactions [1], being a pre-requisite for its for recognition by enzymes or receptors, are among the aspects that motivate its inclusion into new potential bioactive structures. Guanidine-containing molecules have been reported to possess anticancer [5,6], antimicrobial [7-10], antiviral [11,12], anti-inflammatory [13,14], or antiparasitic $[8,15]$ properties and to display inhibitory abilities towards therapeuticallyrelevant enzymes [16-19]. Various guanidine derivatives reached clinical application, from which the antidiabetic metformin [20] or the antimalarial chloroguanide [21] can be highlighted. The guanidine system is present in structural components of biomolecules, namely in the amino acid arginine or in the nucleobase guanine. It is also embodied in the nitrogenous aromatic moiety of various bioactive compounds, such as in the 2aminopurine motif, which is contained in the antibiotic natural nucleosides amipurimycin and miharamycins [22,23], and in various synthetic nucleosides exhibiting anticancer [24] and antiviral properties [25], or in the 2-aminopyrimidine moiety, which is present in the anticancer drug imatinib [26]. On the other hand, the amidine (or imidamide) system $\left(\mathrm{NH}_{2}-\mathrm{C}=\mathrm{NR}\right)$ contained in the guanidine group is present in the cytosine and adeninebased motifs, which are found in various nucleoside analogues used as chemotherapeutic agents [27,28]. Carbohydrate-based molecules possessing guanidine groups have also shown their importance as therapeutic compounds, with important clinically-used molecules such as the natural pseudotrisaccharide antibiotic streptomycin [29] and the antiviral sialic acid mimetic zanamivir [30]. Research reports on guanidino sugars also revealed the ability of iminosugar guanidines to act as glycosidase inhibitors [31-35], while $N$-glycosyl guanidines containing $N^{\prime}$-4-arylthiazol-2-yl groups were described to possess inhibitory activity towards HIV-1 protease and nitric oxide synthase [36]. Other reported guanidino-containing sugar derivatives of biological interest included analogues of $N$-glucosyl arginine [37] and $\beta$-(1 $\rightarrow 6)$-guanidine-linked glucooligomers, which were 
shown to be able to interact with phosphate anions in water through the pseudo interglycosidic guanidine linkage [38]. Oligonucleotide analogues comprising bridging guanidine groups replacing the phosphodiester bond have been synthesized, showing the ability to bind complementary DNA or RNA sequences and resistance to nucleases [3942]. Motivated by the biological profile of guanidine-containing molecules, namely those based on carbohydrate templates, and within our interest in the access to novel bioactive nucleoside analogues and simpler carbohydrates derivatives comprising functional groups contained in nucleoside partial structures, we report herein on the synthesis and biological evaluation of novel 5-guanidino xylofuranose derivatives. These molecules can be foreseen as potential isonucleoside mimetics, in which a system contained in aminopurine/cytosine nucleobases, i.e. the guanidine/amidine group, is linked to a furanose unit at a non-anomeric position. Moreover, a related compound comprising a 1,2,3-triazole unit between $\mathrm{C}-5$ of the sugar moiety and the guanidine group, i.e. guanidinomethyltriazole 5'-isonucleoside, a previously unreported type of nucleoside analogue, was accessed. Different $O$-substituents were installed at C-3 in the furanose moiety, i.e. from small saturated/unsaturated to long hydrocarbon chains and aromaticcontaining systems, including 1,2,3-triazole units, enabling varying the types of interactions that the molecules may establish with a biological target. The molecules were then evaluated for their ability to inhibit cholinesterases (ChEs) and for their anticancer potential. ChEs are therapeutic targets for the symptomatic treatment of Alzheimer's disease $(A D)$ since these enzymes hydrolyze the neurotransmitter acetylcholine, whose level is low in $\mathrm{AD}$ patients [43]. Few examples of guanidine-containing molecules exhibiting cholinesterase inhibitory ability were reported $[16,17,44]$. Moreover, we have previously found the inhibitory effects of aminopurine and guanine isonucleosides on the activity of acetylcholinesterase [45,46], which further motivated us to evaluate the anticholinesterasic activities of simpler guanidine-containing sugar derivatives such as the synthesized 5-guanidino furanoses. All compounds were assessed for their antiproliferative effects on cancer cells.

\section{Results and Discussion}

\subsection{Chemistry}

The synthesis of 3-O-substituted 5-guanidino xylofuranose derivatives involved the access to 5-azido precursors, which could be achieved by different pathways depending on the 3-O-substituent (Scheme 1). One pathway involved the oxidative cleavage of 3-Oallyl, -propargyl [47], -dodecyl [48] and -benzyl [49] 1,2- $O$-isopropylidene glucofuranose derivatives (1-4) with sodium metaperiodate, followed by reduction with sodium borohydride to afford the corresponding xylofuranose derivatives 5-8 for further installation of the azide functionality. This was firstly attempted by a sequence of tosylation (tosyl chloride/pyridine) and further nucleophilic replacement with sodium 
azide, by which the 3-O-dodecyl and 3-O-benzyl 1,2- $O$-isopropylidene xylofuranoses 78 were converted into 14-15 as previously reported [47,48]. In the case of the allyl and propargyl derivatives 5-6, the corresponding intermediate 5-tosylates were reverted to the 5-hydroxyl derivatives upon treatment with the azide anion. The treatment of 5-6 with diphenylphosphoryl azide in the presence of 1,8-diazabicyclo[5.4.0] undec-7-ene (DBU) proved also not to be feasible for the access to the corresponding 5-azido derivatives, leading solely to the xylofuranosyl phosphates 9 and 10 [47] that did not evolve towards the desired azides even after long reaction times (16-24 h), heating $\left(40^{\circ} \mathrm{C}\right)$ and addition of sodium azide. Hence, the 3-O-allyl-5-azido furanose derivative $\mathbf{1 2}$ was synthesized by 3-O-allylation of known 5-azido-1,2-O-isopropylidene xylofuranose (11) [50] with allyl bromide in the presence of sodium hydride in $87 \%$ yield, similarly as for the 3-Opropargylated counterpart $\mathbf{1 3}$ which was obtained via $O$-propargylation of $\mathbf{1 1}$ as previously reported [47].
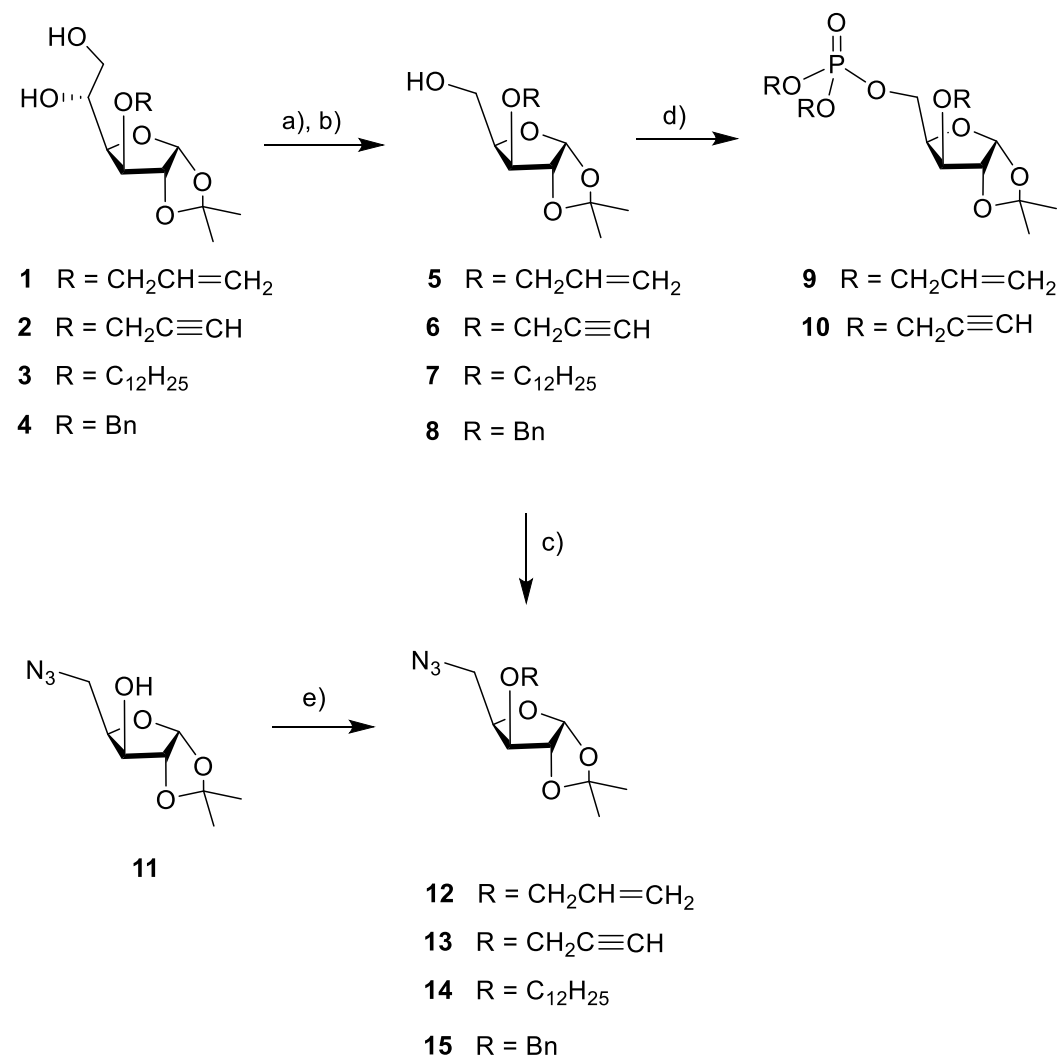

Scheme 1. Reagents and conditions: (a) $\mathrm{NaIO}_{4}$, THF (60-75\% aq. soln.), r. t., 2.5-4 h; (b) $\mathrm{NaBH}_{4}, \mathrm{EtOH} / \mathrm{H}_{2} \mathrm{O}$ (2/1), r. t., 1 h, 58 (5), 57\% (6) [47], 64\% (7) [48], 82\% (8) [49], 2 steps; (c) TsCl, $\mathrm{CH}_{2} \mathrm{Cl}_{2}$ /pyridine (1:1, from 7), pyridine (from 8), r. t., 16 h; (d) $\mathrm{NaN}_{3}$, DMF, $80{ }^{\circ} \mathrm{C}, 16 \mathrm{~h}, 77 \%$ (14) [48], 80\% (15) [47], 2 steps; (d) DPPA, DBU, toluene, $r$. t., $16 \mathrm{~h}$ (from 5), $24 \mathrm{~h}$, then $40^{\circ} \mathrm{C}, 16 \mathrm{~h}$ (from 6), $98 \%$ (9), $68 \%$ (10) [47]; (e) RBr, NaH, DMF, r. t., 16 h (for $\mathrm{R}=\mathrm{C}_{3} \mathrm{H}_{5}$ ), 5 min. (for $\mathrm{R}=\mathrm{C}_{3} \mathrm{H}_{3}$ ), $87 \%$ (12), $95 \%$ (13) [47]. 
The 5-azido xylofuranose derivatives 12-15 were then engaged in reduction/guanidinylation (Scheme 2). A reported one pot-two step procedure, in which the azido sugar is subjected to hydrogenation in the presence of the guanidinylating reagent $N, N^{\prime}$-bis(tert-butoxycarbonyl)- $N N^{\prime \prime}$-triflylguanidine and diisopropylethylamine (DIPEA) [51,52] was firstly used. While this protocol allowed obtaining the 5-guanidino xylofuranose derivatives containing 3-O-dodecyl and 3-O-benzyl groups (19 and 20) in high yields (86-89\%), the latter not being removed under the conditions used, when applied to the 3-O-allyl-5-azido sugar $\mathbf{1 2}$ it led to the 5-guanidino 3-O-propyl xylofuranose 16 in $60 \%$ yield. Hence, to avoid the reduction of the allyl and eventually of the propargyl moiety, an alternative method consisting of the selective reduction of the azide group by the Staudinger reaction with triphenylphosphane in tetrahydrofuran (THF)/water, followed by guanidinylation, was employed. The 3-O-allyl and 3-O-propyl 5-guanidino sugars 17-18 were thus obtained from the azido derivatives 12-13, respectively, by this methodology in very good yields (88-95\%). The 3-O-dodecyl and 3$O$-benzyl 5-azido xylofuranoses 14-15 were also subjected to the Staudinger/guanidinylation protocol leading to the corresponding guanidine sugars 19-20 in comparable yields as those obtained by the one-pot hydrogenation/guanydinilation method.

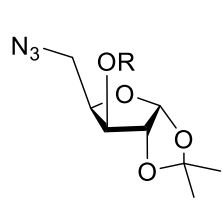

$$
12 \mathrm{R}=\mathrm{CH}_{2} \mathrm{CH}=\mathrm{CH}_{2}
$$$$
13 \mathrm{R}=\mathrm{CH}_{2} \mathrm{C} \equiv \mathrm{CH}
$$$$
14 \mathrm{R}=\mathrm{C}_{12} \mathrm{H}_{25}
$$$$
15 \mathrm{R}=\mathrm{Bn}
$$

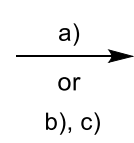

b), c)

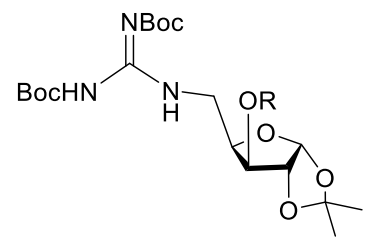

$16 \mathrm{R}=\mathrm{CH}_{2} \mathrm{CH}_{2} \mathrm{CH}_{3}$

$17 \mathrm{R}=\mathrm{CH}_{2} \mathrm{CH}=\mathrm{CH}_{2}$

$18 \mathrm{R}=\mathrm{CH}_{2} \mathrm{C} \equiv \mathrm{CH}$

$19 \mathrm{R}=\mathrm{C}_{12} \mathrm{H}_{25}$

$20 \mathrm{R}=\mathrm{Bn}$

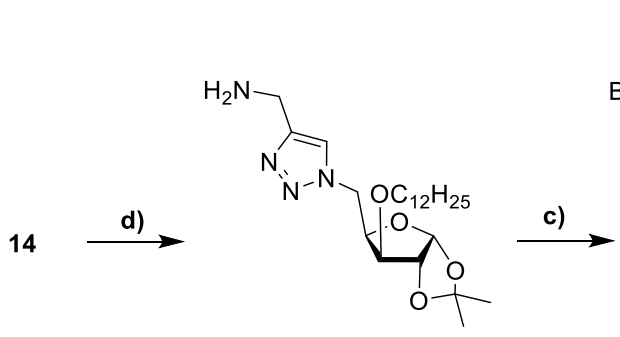

21

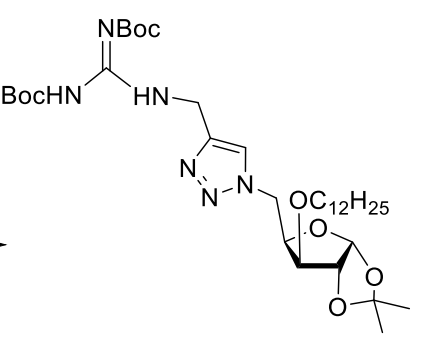

22

Scheme 2. Reagents and conditions: (a) $N, N^{\prime}$-diBoc- $N$ "'-triflylguanidine, $\mathrm{H}_{2}, 10 \% \mathrm{Pd} / \mathrm{C}$, DIPEA, AcOEt, 16 h, 16 (60\%), 19 (86\%), 20 (89\%); (b) $\mathrm{PPh}_{3}, \mathrm{THF} / \mathrm{H}_{2} \mathrm{O}$ (13/1), r. t., 4 h (for 12-15), 24 h (for 21); (c) $N, N^{\prime}$-diBoc- $N N^{\prime \prime}$-triflylguanidine, DIPEA, AcOEt, r. t., 45 min (for 12-15), 10 h (for 21), 17 (88\%), 18 (95\%), 19 (81\%), 20 (83\%), 2 steps, 2222 (54\%); (d) propargylamine, toluene, $110^{\circ} \mathrm{C}, 24 \mathrm{~h}, 20 \%$ [47]. 
The access to a 3-O-dodecyl xylofuranose derivative including a 1,2,3-triazole moiety, which is a stable unit prompted to establish hydrogen-bond and $\pi$-stacking interactions with amino acid-residues, between the sugar and the guanidino moieties was then accomplished. Nucleoside analogues containing a 3-O-dodecyl xylofuranose system were previously described as possessing antiproliferative activities in cancer cells [48]. Hence the aminomethyltriazole 21, whose synthesis was previously described via thermal cycloaddition between the 5-azido 3-O-dodecyl xylofuranose 14 and propargylamine [47] was subjected to guanidinylation leading to the guanidinomethyltriazole 5'-isonucleoside 22 in $54 \%$ yield.

A 5-guanidino sugar containing a 3-O-substituent combining a benzyl moiety with a triazole motif was also synthesized (Scheme 3 ). Hence, the previously reported 5-azido3-O-(benzyltriazolyl)methyl xylofuranose derivative 23, accessed from $\mathbf{1 3}$ via 1,3-dipolar cycloaddition with benzyl azide and further azidation [47], was subjected to Staudinger reduction followed by guanidinylation leading to the 5-guanidino 3'- $O$-methyl-branched $\mathrm{N}$-benzyltriazole isonucleoside $\mathbf{2 4}$ in $\mathbf{8 4 \%}$ yield. Alternatively, $\mathbf{2 4}$ could be obtained through "click" cycloaddition between $\mathbf{1 8}$ with benzyl azide in the presence of copper iodide/Amberlyste A-21 [53] in 38\% yield with the 5-iodotriazole 25 being also formed as secondary product in $10 \%$ yield. Identification of $\mathbf{2 5}$ was based on its NMR data, with the absence of the signal corresponding to $\mathrm{H}-3$ ' on the ${ }^{1} \mathrm{H}$ NMR spectrum and the chemical shift difference between the triazole quaternary carbon signals in the ${ }^{13} \mathrm{C}$ NMR spectrum resonating at $\delta=148.3\left(\mathrm{C}-2^{\prime}\right)$ and $\delta=80.8\left(\mathrm{C}-3^{\prime}\right) \mathrm{ppm}$. The formation of iodotriazoles has been reported in $\mathrm{CuI}$-catalyzed azide-alkyne cycloadditions in the presence of organic bases [54-56]. The Amberlyst A-21 resin, onto which CuI is supported, appears to be able to elicit triazole iodination due to its dimethylamino groups. The use of copper iodide as a promoter in an equimolar amount relatively to $\mathbf{1 8}$ and a catalytic amount of 4dimethylaminopyridine (DMAP) as base, conditions previously reported to increase triazole iodination [56], in a dilute dichloromethane solution at $30^{\circ} \mathrm{C}$, led solely to the iodotriazole 25 in $66 \%$ yield. 


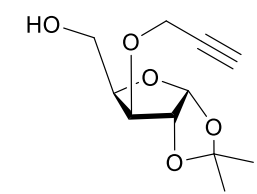

13

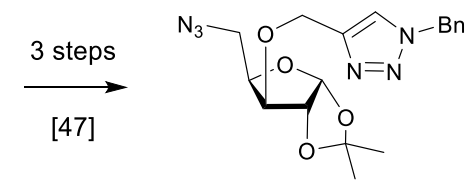

23

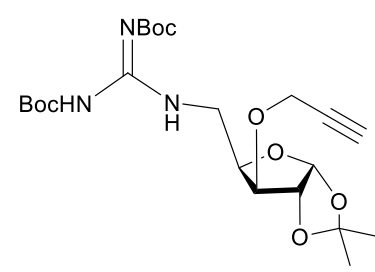

18

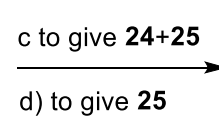

d) to give 25

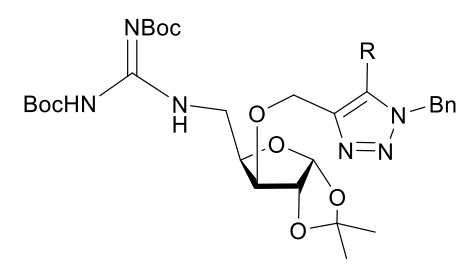

$24 \mathrm{R}=\mathrm{H}$

$25 \mathrm{R}=$ ।

Scheme 3. (a) $\mathrm{PPh}_{3}, \mathrm{THF} / \mathrm{H}_{2} \mathrm{O}(10 / 1)$, r. t., 4 h; (b) $N, N^{\prime}$-diBoc- $N^{\prime \prime}$-triflylguanidine, DIPEA, AcOEt, r. t., 2 h, 84\%, 2 steps. (c) $\mathrm{BnN}_{3}$, cat. CuI/A-21, $\mathrm{CH}_{2} \mathrm{Cl}_{2}, 4$ d, 22 (38\%), 23 (10\%). (d) $\mathrm{BnN}_{3}$, CuI, cat. DMAP, $\mathrm{CH}_{2} \mathrm{Cl}_{2}, 30{ }^{\circ} \mathrm{C}, 72 \mathrm{~h}, 66 \%$.

The 3-O-benzyl and 3-O-dodecyl 5-guanidino xylofuranoses 19 and 20 were subjected to $t$-butoxycarbonyl group (Boc) and 1,2-O-acetonide removal through treatment with trifluoroacetic acid (TFA) in the presence of triethylsilane acting as tert-butyl cation scavenger [57-58]. While both carbamate functions of the 3-O-benzyl derivative $\mathbf{2 0}$ were cleaved, leading to the deprotected 5-guanidino xylofuranose 27 in $36 \%$ yield, the $3-O$ dodecyl counterpart underwent selective removal of imino N-Boc group under similar conditions to afford the N-Boc-monoprotected guanidine 26 in $26 \%$ yield. Both compounds were obtained as anomeric mixtures with $\alpha / \beta$ ratios close to $1: 1$. No products resulting from cyclization involving the guanidine amino groups and the anomeric center, i.e. guanidine-type iminosugar derivatives [33, 52, 59], were detected.

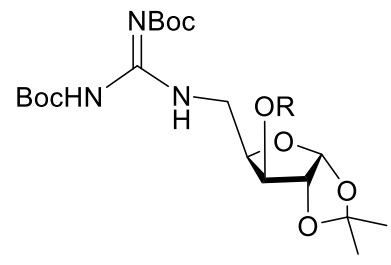

$19 \mathrm{R}=\mathrm{C}_{12} \mathrm{H}_{25}$

$20 \mathrm{R}=\mathrm{Bn}$
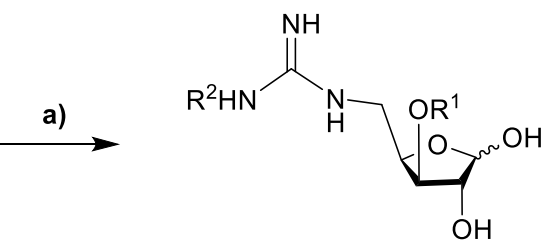

$26 \mathrm{R}^{1}=\mathrm{C}_{12} \mathrm{H}_{25}, \mathrm{R}^{2}=\mathrm{Boc}$

$27 \mathrm{R}^{1}=\mathrm{Bn} ; \mathrm{R}^{2}=\mathrm{H}$

Scheme 4. (a) TFA/ $\mathrm{H}_{2} \mathrm{O} /$ triethylsilane 48:1:1, r.t., 2 h, 26 (33\%), 27 (36\%). 


\subsection{Biological Evaluation}

All newly synthesized guanidine derivatives (16-20, 22, 24-27) as well as the aminomethyltriazole isonucleoside $\mathbf{2 1}$, precursor of guanidine $\mathbf{2 2}$, were subjected to biological evaluation, focusing on the study of their ability to inhibit cholinesterases and on their antiproliferative effects in cancer cells.

\subsubsection{Cholinesterase Inhibition}

The inhibitory effects of the compounds on the activities of acetylcholinesterase (AChE, from Electrophorus electricus) and butyrylcholinesterase (BChE, from equine serum) were evaluated by the Ellman's assay. The cholinesterase inhibitor galantamine hydrobromide $(\mathrm{GH})$, which is commonly used in AD symptomatic therapy, was included as a reference. The inhibition constants, which were determined for the significantly active molecules, i.e., those that showed more than 50\% inhibition of the enzymatic activity at $10 \mu \mathrm{M}$ concentration, and their types of inhibition are presented in Table 1.

Table 1. Significant results on the evaluation of the inhibitory effects of the compounds on the activity of cholinesterases.; inhibition constants $K_{\mathrm{i}}$ (for competitive inhibition) and $K_{\mathrm{i}^{\prime}}$ (for uncompetitive inhibition) are reported in $\mu \mathrm{M}$; the results are mean values resulting from triplicate experiments.

\begin{tabular}{ccccc}
\hline & \multicolumn{2}{c}{ AChE } & \multicolumn{2}{c}{ BChE } \\
\hline Compound & \% Inhibition & $\begin{array}{c}K_{\mathrm{i}} \\
{\left[\mathrm{K}_{\mathrm{i}}{ }^{\prime}\right]} \\
\text { (type of inhibition) }\end{array}$ & \% Inhibition & $\begin{array}{c}K_{\mathrm{i}} \\
{\left[K_{\mathrm{i}}{ }^{\prime}\right]} \\
\text { (type of inhibition) }\end{array}$ \\
\hline $\mathbf{2 H}$ & 96.7 & $\begin{array}{c}0.54 \pm 0.01 \\
\text { (competitive) }\end{array}$ & 86.3 & $\begin{array}{c}9.37 \pm 0.67 \\
\text { (competitive) }\end{array}$ \\
\hline \multirow{2}{*}{$\mathbf{2 2}$} & 79.53 & $\begin{array}{c}22.87 \pm 3.83 \\
{[89.18 \pm 1.8]} \\
\text { (mixed-type) }\end{array}$ & 21.69 & n.d. \\
\hline \multirow{2}{*}{$\mathbf{2 6}$} & $\begin{array}{c}7.49 \pm 0.92 \\
{[7.69 \pm 1.62]} \\
\text { (non-competitive) }\end{array}$ & 37.76 & n.d. \\
\hline
\end{tabular}

The guanidinomethyltriazole 5 '-isonucleoside 22 and the 3-O-dodecyl ( $N$-Boc)guanidino xylofuranose derivative $\mathbf{2 6}$ were the active compounds of the series, exhibiting selectivity towards AChE. The isonucleoside 22 showed moderate mixed-type AChE inhibition, the competitive component of which is more pronounced than the uncompetitive one $\left(K_{\mathrm{i}}=\right.$ $22.87 \mu \mathrm{M}, K_{\mathrm{i}}{ }^{\prime}=89.18 \mu \mathrm{M}$, Figure 1). Since the aminomethyltriazole isonucleoside 21 did 
not show significant $\mathrm{AChE}$ inhibition, it appears that the presence of the guanidine moiety in $\mathbf{2 2}$ is important for its inhibitory effect.
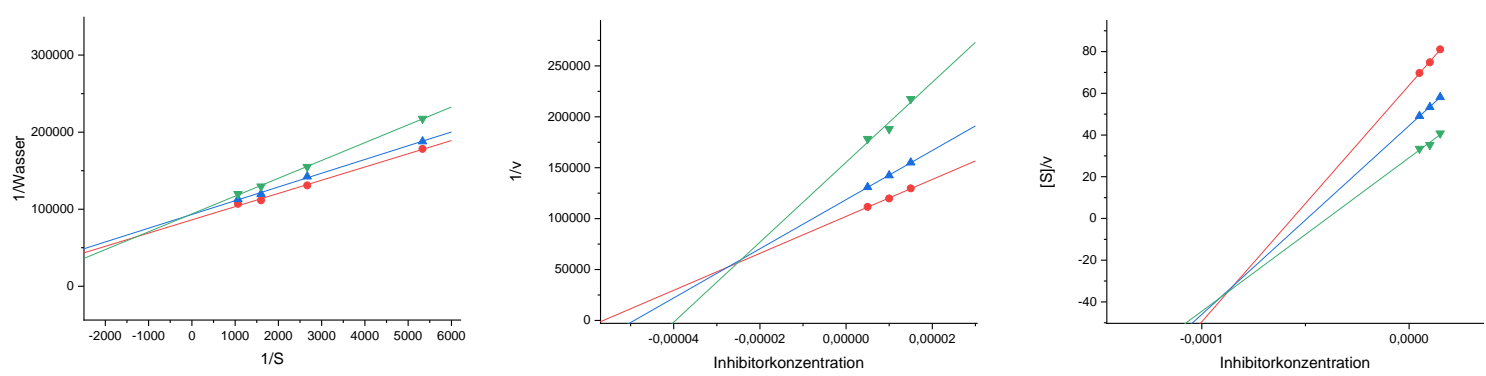

Figure 1. Lineweaver-Burk (left), Dixon (center) and Cornish-Bowden (right) plots for the inhibition of AChE by compound 22.

The isonucleoside 26 was the best AChE inhibitor with single-digit micromolar values of inhibition constants and exhibiting a non-competitive effect $\left(K_{\mathrm{i}}=7.49 \mu \mathrm{M}, K_{\mathrm{i}}{ }^{\prime}=7.69\right.$ $\mu \mathrm{M}$, Figure 2).
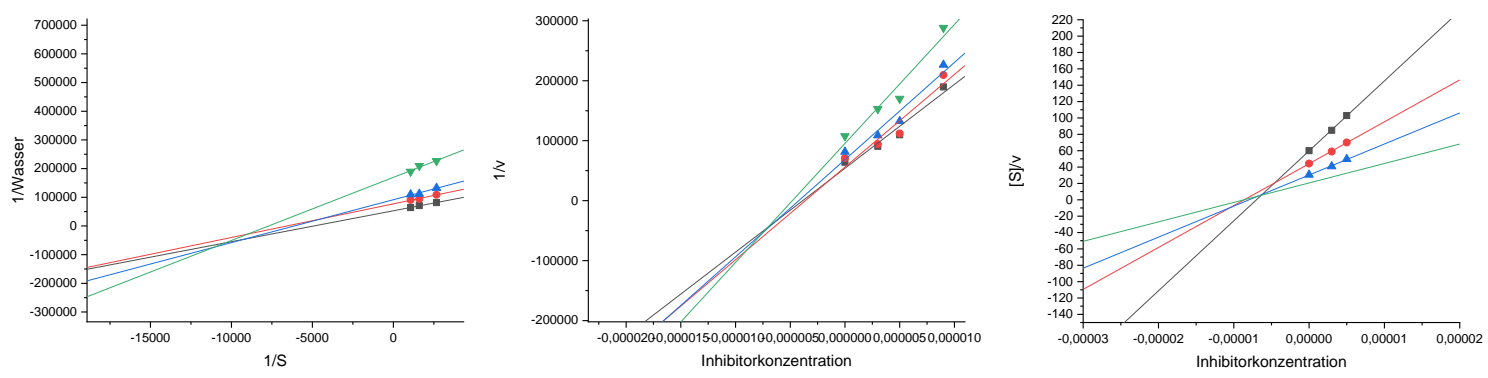

Figure 2. Lineweaver-Burk (left), Dixon (center) and Cornish-Bowden (right) plots for the inhibition of AChE by compound 26.

\subsubsection{Antiproliferative Activity}

The antiproliferative activities of the compounds were evaluated in K562 (chronic myeloid leukemia) and in MCF-7 (breast adenocarcinoma) cell lines by the rezasurin (Alamar Blue) assay. The 3-O-dodecyl-5-( $N^{\prime}, N^{\prime}$-di-Boc)guanidino-1,2-O-isopropylidene xylofuranose derivative 19, the aminomethyltriazole isonucleoside 21 and the 3-Ododecyl ( $N$-Boc)guanidino xylofuranose 26 were the compounds that showed significant effects. The 3-O-dodecyl guanidine 19 exhibited modest and similar activities towards $\mathrm{K} 562\left(\mathrm{GI}_{50}=47.5 \mu \mathrm{M}\right)$ and MCF-7 $\left(\mathrm{GI}_{50}=41.68 \mu \mathrm{M}\right)$ cells. Removal of the imine Boc group and of the 1,2-acetonide function of $\mathbf{1 9}$ leading to $\mathbf{2 6}$ enabled a 1,5-fold increase in the antiproliferative activities in both K562 and MCF-7 cell lines, with GI 50 values for 26 of $31.02 \mu \mathrm{M}$ and $26.89 \mu \mathrm{M}$, respectively. The most effective compound in the panel was 
the aminomethyltriazole derivative $\mathbf{2 1}$ displaying low micromolar antiproliferative activities with $\mathrm{GI}_{50}$ values of $6.33 \mu \mathrm{M}$ and $8.45 \mu \mathrm{M}$ in $\mathrm{K} 562$ and in MCF-7 cells, respectively. Noteworthy to mention is that the GI 50 value of 21 in MCF-7 cells is similar to that of the reference anticancer drug 5-fluorouracil.

Table 1. Compounds' antiproliferative activities in K562 and MCF-7 cell lines.

\begin{tabular}{ccc}
\hline \multirow{2}{*}{ Compound } & \multicolumn{2}{c}{$\mathbf{G I}_{50}(\boldsymbol{\mu M})^{*}$} \\
\cline { 2 - 3 } & $\mathbf{K 5 6 2}$ & MCF-7 \\
$\mathbf{1 6}$ & $>50$ & $>50$ \\
$\mathbf{1 8}$ & $>100$ & $>100$ \\
$\mathbf{1 9}$ & 47.53 & 41.68 \\
$\mathbf{2 0}$ & $>25$ & $>25$ \\
$\mathbf{2 1}$ & 6.33 & 8.45 \\
$\mathbf{2 2}$ & $>25$ & $>25$ \\
$\mathbf{2 4}$ & $>6.25$ & $>6.25$ \\
$\mathbf{2 5}$ & $>6.25$ & $>6.25$ \\
$\mathbf{2 6}$ & 31.02 & 26.89 \\
$\mathbf{2 7}$ & $>100$ & $>100$ \\
imatinib & $0.47 \pm 0.02$ & $26.8 \pm 2.0$ \\
5-fluorouracil & $>100$ & $9.7 \pm 0.0$ \\
\hline
\end{tabular}

*tested at least in duplicate.

\section{Conclusions}

A diversity of guanidine-containing xylofuranose derivatives were synthesized from azido or amino precursors using the guanidinylation with $N, N^{\prime}$-bis(tert-butoxycarbonyl)$N^{\prime \prime}$-triflylguanidine as key step. The panel of synthesized molecules included 5-guanidino 3- $O$-substituted xylofuranoses (16-20, 24-25), including 5-guanidino 3- $O$-methylbranched $N$-benzyltriazole isonucleosides (24-25), a novel type of structural framework, and the guanidinomethyltriazole xylofuranos-5'-yl isonucleoside 22, which also comprises a previously unreported type of structure. These molecules may be foreseen as potential nucleoside mimetics since the guanidine function is present in nucleobase derivatives and due to the presence of the triazole system as well in some of them. Conditions for click chemistry cycloaddition from the 5-guanidino-3-O-propargyl xylofuranose precursor 18 were established for obtaining predominantly the 5-guanidino $\mathrm{N}$-benzyltriazole isonucleoside $\mathbf{2 4}$, by using a CuI/Amberlyst A-21 catalytic system, or for accessing solely its related 5-iodotriazole derivative 25, by using an equimolar amount of $\mathrm{CuI}$ and catalytic DMAP. 
From the molecules tested, two demonstrated significant AChE inhibitory abilities and three showed antiproliferative effects in K526 and MCF-7 cells. The most active compounds exhibited $K_{\mathrm{i}}$ and $\mathrm{GI}_{50}$ values in the low micromolar order of concentration, namely the ( $N$-Boc)guanidino xylofuranose 26, the best $\mathrm{AChE}$ inhibitor and the aminomethyltriazole 5'-isonucleoside 21, precursor of the guanidinomethyltriazole isonucleoside $\mathbf{2 2}$, as the most potent antiproliferative compound. Its activity against the MCF-7 cell line is similar to that of the reference drug 5-fluorouracil, which turns it a promising anticancer lead molecule. Although the antiproliferative activity of the guanidinomethyltriazole 5'-isonucleoside 22 could not be determined ( $\mathrm{GI}_{50}>25 \mu \mathrm{M}$ ), the lack of activity of this compound at concentrations below $25 \mu \mathrm{M}$ clearly indicates that the inclusion of a guanidine moiety in $\mathbf{2 1}$ leads to a decrease in the antiproliferative effect of the structure. On the other hand, the isonucleoside 22, unlike its precursor aminomethyltriazole 21, displayed moderate selective inhibition of AChE, which indicates the importance of the guanidine moiety for recognition by the enzyme and shows the interest of this structural framework in the search for new AChE inhibitors.

Given that all significant active compounds in the biological screening comprise a 3-Ododecyl substituent, the presence of this hydrophobic chain appears to be crucial for the detected effects, reinforcing the therapeutic interest of 3-O-dodecyl xylofuranosyl nucleoside analogues/mimetics.

To the best of our knowledge, this contribution presents the first reported examples of guanidine-containing sugar derivatives displaying $\mathrm{AChE}$ inhibition and antiproliferative effects in cancer cells, demonstrating, therefore, the potential of such structures for the discovery of lead molecules for $\mathrm{AD}$ and cancer.

\section{Materials and Methods}

\subsection{Chemistry}

\subsubsection{General Methods}

Chemical reactants were purchased from Sigma-Aldrich and Alfa Aesar. The reactions were followed by TLC using Merck $60 \mathrm{~F}_{254}$ silica gel aluminium plates. Spots were visualized under UV light $(254 \mathrm{~nm})$ and/or after immersion in a 10\% (v/v) ethanolic $\mathrm{H}_{2} \mathrm{SO}_{4}$ solution or in the Hanessian's stain (solution of cerium (IV) sulfate $(0.2 \% \mathrm{w} / \mathrm{v}$ ) and ammonium molybdate (5\% w/v) in $\mathrm{H}_{2} \mathrm{SO}_{4}(6 \%$ aq. $)$ ) followed by charring with a heat gun $\left(200{ }^{\circ} \mathrm{C}\right)$. Compounds were purified by flash column chromatography on silica gel $60 \mathrm{G}(0.040-0.063 \mathrm{~mm}$, E. Merck). NMR experiments were carried out using a BRUKER Avance 400 spectrometer operating at $400.13 \mathrm{MHz}$ (for ${ }^{1} \mathrm{H} \mathrm{NMR}$ ), $100.62 \mathrm{MHz}$ (for ${ }^{13} \mathrm{C}$ NMR) or at $161.91 \mathrm{MHz}$ (for ${ }^{31} \mathrm{P}$ NMR). Spectra were referenced to internal TMS, in the case of ${ }^{1} \mathrm{H}$ NMR spectra in $\mathrm{CDCl}_{3}$, or to the respective solvent peak. ${ }^{31} \mathrm{P}$ NMR Spectra 
were referenced following the IUPAC recommendations for chemical shift referencing [60]. 2D NMR experiments (COSY, HSQC, HMBC) were performed for supporting signal assignment. Chemical shifts are given in parts per million and coupling constants (J) are reported in Hertz (Hz). High-resolution mass spectrometry (HRMS) data were obtained on a High Resolution QqTOF Impact II mass spectrometer from Bruker Daltonics equipped with an electrospray ion source (ESI). Spectra were recorded in positive mode with external calibration. Melting points were determined with a Stuart SMP30 instrument. Optical rotations $\left(589 \mathrm{~nm}\right.$, sodium D line, $\left.20^{\circ} \mathrm{C}\right)$ were measured using a Perkin-Elmer 343 polarimeter.

Synthesis of compounds 6-8 [47-49], 10 [47], and 13-15 [47,48] was previously described.

\subsubsection{3-O-Allyl-1,2-O-isopropylidene- $\alpha$-D-xylofuranose (5)}

To a solution of 3- $O$-allyl-1,2- $O$-isopropylidene- $\alpha$-D-glucofuranose $(1,0.5 \mathrm{~g}, 1.92 \mathrm{mmol})$ in $\mathrm{THF} / \mathrm{H}_{2} \mathrm{O}(8 \mathrm{~mL}, 3: 1)$, at $0{ }^{\circ} \mathrm{C}$, sodium metaperiodate $(0.95 \mathrm{~g}, 4.44 \mathrm{mmol})$ was added. The mixture was stirred for $4 \mathrm{~h}$ at room temperature. Then, it was diluted with EtOAc and filtered over a pad of Celite. The phases were separated, the aqueous phase was extracted with AcOEt $(2 \times)$ and the combined organic layers were dried with anhydrous $\mathrm{MgSO}_{4}$. After filtration and concentration under vacuum, the crude residue was dissolved in $\mathrm{EtOH} / \mathrm{H}_{2} \mathrm{O}(15 \mathrm{~mL}, 3: 1)$ and at. $0{ }^{\circ} \mathrm{C}, \mathrm{NaBH}_{4}(61 \mathrm{~m} \mathrm{~g}, 1.58 \mathrm{mmol})$ was added. The mixture was stirred at room temperature for $1 \mathrm{~h}$. Then, EtOAc was added. The mixture was washed with brine soln. and the aqueous phase was extracted with EtOAc $(2 \times)$. The combined organic layers were dried with anhydrous $\mathrm{MgSO}_{4}$, filtered and concentrated. The residue was subjected to column chromatography (AcOEt/hexane, 1:4) to afford 5 $(0.256 \mathrm{~g}, 58 \%, 2$ steps $)$ as a yellow oil. $[\alpha]_{D}^{20}=-36\left(\mathrm{c}=1\right.$, in $\left.\mathrm{CH}_{2} \mathrm{Cl}_{2}\right) .{ }^{1} \mathrm{H} \mathrm{NMR}\left(\mathrm{CDCl}_{3}\right.$, $400 \mathrm{MHz}): \delta=5.95$ (d, $\left.1 \mathrm{H}, \mathrm{H}-1,{ }^{3} J_{1,2}=3.8\right), 5.84$ (m, $\left.1 \mathrm{H}, \mathrm{H}-2^{\prime}\right), 5.27$ (dq, $1 \mathrm{H}, \mathrm{H}-3^{\prime} \mathrm{a}$, $\left.J_{2^{\prime}, 3^{\prime} \mathrm{a}}=17.2, J_{1^{\prime} \mathrm{a}, 3^{\prime} \mathrm{a}}=J_{1^{\prime} \mathrm{b}, 3^{\prime} \mathrm{a}}=J_{3^{\prime} \mathrm{a}, 3^{\prime} \mathrm{a}}=1.4\right), 5.21\left(\mathrm{dq}, 1 \mathrm{H}, \mathrm{H}-33^{\prime} \mathrm{b}, J_{2^{\prime}, 3^{\prime} \mathrm{b}}=10.5, J_{1^{\prime} \mathrm{a}, 3^{\prime} \mathrm{b}}=J_{1^{\prime} \mathrm{b}, 3^{\prime} \mathrm{b}}\right.$ $\left.=J_{3^{\prime} \mathrm{a}, 3^{\prime} \mathrm{a}}=1.4\right), 4.56(\mathrm{~d}, 1 \mathrm{H}, \mathrm{H}-2), 4.27(\mathrm{ddd}, 1 \mathrm{H}, \mathrm{H}-4), 4.14\left(\mathrm{ddt}, 1 \mathrm{H}, \mathrm{H}-1^{\prime} \mathrm{a}, J_{1^{\prime} \mathrm{a}, 1^{\prime} \mathrm{b}}=\right.$ $\left.13.0, J_{1^{\prime} \mathrm{a}, 2^{\prime}}=5.2, J_{1^{\prime} \mathrm{a}, 3^{\prime} \mathrm{a}}=J_{1^{\prime} \mathrm{a}, 3^{\prime} \mathrm{b}}=1.4\right), 4.01-3.89\left(\mathrm{~m}, 3 \mathrm{H}, \mathrm{H}-1^{\prime} \mathrm{b}, \mathrm{H}-3, \mathrm{H}-5 \mathrm{a}, J_{3,4}=3.4, J_{4,5 \mathrm{a}}\right.$ $\left.=5.2, J_{5 \mathrm{a}, 5 \mathrm{~b}}=12.1\right), 3.85$ (dd, part B of ABX system, H-5b, $\left.J_{4,5 \mathrm{~b}}=4.7\right), 2.30$ (br.s, $1 \mathrm{H}$. $\mathrm{OH}-5), 1.47$ (s, $3 \mathrm{H}, \mathrm{CH}_{3}, i$-Pr), 1.30 (s, $3 \mathrm{H}, \mathrm{CH}_{3}, i$-Pr) ppm. ${ }^{13} \mathrm{C} \mathrm{NMR}\left(\mathrm{CDCl}_{3}, 400\right.$ MHz): $\delta=133.7\left(\mathrm{C}-2^{\prime}\right), 118.2\left(\mathrm{C}-3^{\prime}\right), 111.8(\mathrm{Cq}, i$-Pr), $105.1(\mathrm{C}-1), 83.0$ (C-3), 82.6 (C2), 80.1 (C-4), $71.0\left(\mathrm{C}-1^{\prime}\right), 61.1(\mathrm{C}-5), 26.9\left(\mathrm{CH}_{3}, i\right.$-Pr), $26.4\left(\mathrm{CH}_{3}, i\right.$-Pr) ppm. HRMS: calcd for $\mathrm{C}_{11} \mathrm{H}_{18} \mathrm{O}_{5}[\mathrm{M}+\mathrm{H}]^{+} 231.1227$, found 231.1235; calcd for $\mathrm{C}_{11} \mathrm{H}_{18} \mathrm{O}_{5}[\mathrm{M}+\mathrm{Na}]^{+}$ 253.1046, found 253.1058. 
4.1.3. Diphenyl (3-O-allyl-5-deoxy-1,2-O-isopropylidene- $\alpha$-D-xylofuranos-5yl)phosphate (9)

To a solution of 3- $O$-allyl-1,2- $O$-isopropylidene- $\alpha$-D-xylofuranose $(\mathbf{5}, 0.71 \mathrm{~g}, 3.08 \mathrm{mmol})$ in toluene $(16 \mathrm{~mL})$ at $0{ }^{\circ} \mathrm{C}$ and under nitrogen atnosphere, diphenylphosphoryl azide (DPPA, $0.9 \mathrm{~mL}, 4.18 \mathrm{mmol}$ ) and 1,8-diazabicyclo[5.4.0]undec-7-ene (DBU (0.65 mL, $4.35 \mathrm{mmol}$ ) were added and the mixture was stirred at room temperature for $16 \mathrm{~h}$. The mixture was then washed twice with $2 \mathrm{M} \mathrm{HCl}$ soln. and water. The organic phase was dried with anhydrous magnesium sulfate, filtered and the solvent was evaporated under vacuum. The crude residue was subjected to column chromatography (EtOAc/hexane, 1:4) to afford $9(1.40 \mathrm{~g}, 98 \%)$ as a colourless oil. $[\alpha]_{D}^{20}=-43\left(\mathrm{c}=1\right.$, in $\left.\mathrm{CH}_{2} \mathrm{Cl}_{2}\right) .{ }^{1} \mathrm{H}$ NMR $\left(\mathrm{CDCl}_{3}, 400 \mathrm{MHz},\right): \delta=7.42-7.08(\mathrm{~m}, 10 \mathrm{H}, \mathrm{CH}, 2 \times \mathrm{Ph}), 5.92\left(\mathrm{~d}, 1 \mathrm{H}, \mathrm{H}-1, J_{1,2}=3.7\right)$, $5.79\left(\mathrm{~m}, 1 \mathrm{H}, \mathrm{H}-2^{\prime}\right), 5.23\left(\mathrm{dq}, 1 \mathrm{H}, \mathrm{H}-3^{\prime} \mathrm{a}, J_{2^{\prime}, 3^{\prime} \mathrm{a}}=17.2, J_{1^{\prime} \mathrm{a}, 3^{\prime} \mathrm{a}}=J_{1^{\prime} \mathrm{b}, 3^{\prime} \mathrm{a}}=J_{3^{\prime} \mathrm{a}, 3^{\prime} \mathrm{a}}=1.4\right), 5.16$ $\left(\mathrm{dq}, 1 \mathrm{H}, \mathrm{H}-3^{\prime} \mathrm{b}, J_{2^{\prime}, 3^{\prime} \mathrm{b}}=10.4, J_{1^{\prime} \mathrm{a}, 3^{\prime} \mathrm{b}}=J_{1^{\prime} \mathrm{b}, 3^{\prime} \mathrm{b}}=J_{3^{\prime} \mathrm{a}, 3^{\prime} \mathrm{a}}=1.4\right), 4.58-4.39(\mathrm{~m}, 4 \mathrm{H}, \mathrm{H}-2, \mathrm{H}-4$, H-5a, H-5b), 4.06 (ddt, $1 \mathrm{H}, \mathrm{H}-1^{\prime} \mathrm{a}, J_{1^{\prime} \mathrm{a}, 1^{\prime} \mathrm{b}}=12.8, J_{1^{\prime} \mathrm{a}, 2^{\prime}}=5.2, J_{1^{\prime} \mathrm{a}, 3^{\prime} \mathrm{a}}=J_{1^{\prime} \mathrm{a}, 3^{\prime} \mathrm{b}}=1.4$ ), 3.943.84 (m, $2 \mathrm{H}, \mathrm{H}-1^{\prime} \mathrm{b}, \mathrm{H}-3, J_{1^{\prime} \mathrm{b}, 2^{\prime}}=5.7, J_{3,4}=2.3$ ), 1.46 (s, $3 \mathrm{H}, \mathrm{CH}_{3}, i-\mathrm{Pr}$ ), 1.30 (s, $3 \mathrm{H}$, $\mathrm{CH}_{3}, i$-Pr) ppm. ${ }^{13} \mathrm{C} \mathrm{NMR}\left(\mathrm{CDCl}_{3}, 100 \mathrm{MHz}\right.$ ): $\delta=150.40\left(\mathrm{~d}, \mathrm{Cq}, \mathrm{Ph},{ }^{2} J_{\mathrm{C}, \mathrm{P}}=7.2\right), 150.38$ $\left(\mathrm{d}, \mathrm{Cq}, \mathrm{Ph},{ }^{2} J_{\mathrm{C}, \mathrm{P}}=7.2\right), 133.6\left(\mathrm{C}-2^{\prime}\right), 130.0,129.8,126.1,125.4,120.2,120.0(\mathrm{CH}, 2 \times$ $\left.\mathrm{Ph},{ }^{3} J_{\mathrm{C}, \mathrm{P}}=4.8,{ }^{3} J_{\mathrm{C}, \mathrm{P}}=4.9\right), 117.9\left(\mathrm{C}-3^{\prime}\right), 111.9(\mathrm{Cq}, i-\mathrm{Pr}), 105.2(\mathrm{C}-1), 82.1(\mathrm{C}-2), 81.1$ $(\mathrm{C}-3), 78.5\left(\mathrm{~d}, \mathrm{C}-4,{ }^{3} J_{\mathrm{C}-4, \mathrm{P}}=8.6\right), 71.0\left(\mathrm{C}-1^{\prime}\right), 66.1\left(\mathrm{~d}, \mathrm{C}-5,{ }^{2} J_{\mathrm{C}-5, \mathrm{P}}=5.8\right), 26.8\left(\mathrm{CH}_{3}, i\right.$-Pr $)$, $26.2\left(\mathrm{CH}_{3}, i\right.$-Pr) ppm. ${ }^{31} \mathrm{P}$ NMR (162 MHz, $\left.\mathrm{CDCl}_{3}\right): \delta=-12.10 \mathrm{ppm}$. HRMS: calcd for $\mathrm{C}_{23} \mathrm{H}_{27} \mathrm{O}_{8} \mathrm{P}[\mathrm{M}+\mathrm{H}]^{+}$463.1516, found 463.1527; calcd for $\mathrm{C}_{23} \mathrm{H}_{27} \mathrm{O}_{8} \mathrm{P}[\mathrm{M}+\mathrm{Na}]^{+}$ 485.1336, found 485.1348 .

\subsubsection{3-O-Allyl-5-azido-5-deoxy-1,2-O-isopropylidene- $\alpha$-D-xylofuranose (12)}

To a solution of 5-azido-5-deoxy-1,2- $O$-isopropylidene- $\alpha$-D-xylofuranose $(\mathbf{1 1}, 380 \mathrm{mg}$, $1.76 \mathrm{mmol})$ in DMF $(10 \mathrm{~mL})$, at $0^{\circ} \mathrm{C}$ and under nitrogen atmosphere, sodium hydride (60\% in mineral oil, $84 \mathrm{mg}, 2.1 \mathrm{mmol}$ ) was added. After stirring during $10 \mathrm{~min}$, allyl bromide $(0.18 \mathrm{~mL}, 2.1 \mathrm{mmol})$ was added. The reaction was stirred at room temperature overnight. Then, the mixture was diluted with diethyl ether and water was added. The phases were separated, and the aqueous phase was extracted with diethyl ether $(2 \times)$. The combined organic layers were dried with anhydrous $\mathrm{MgSO}_{4}$. After filtration and evaporation of the solvent in vacuum, the crude residue was subjected to column chromatography (AcOEt/hexane, 1:4) to afford $12(391 \mathrm{mg}, 87 \%)$ as a yellow oil. $[\alpha]_{D}^{20}=$ $-28\left(\mathrm{c}=1\right.$, in $\left.\mathrm{CH}_{2} \mathrm{Cl}_{2}\right) .{ }^{1} \mathrm{H}$ NMR $\left(\mathrm{CDCl}_{3}, 400 \mathrm{MHz}\right): \delta=5.92-5.80\left(\mathrm{~m}, 2 \mathrm{H}, \mathrm{H}-1, \mathrm{H}-2^{\prime}\right.$,

$\left.{ }^{3} J_{1,2}=3.6\right), 5.28\left(\mathrm{dq}, 1 \mathrm{H}, \mathrm{H}-3^{\prime} \mathrm{a}, J_{2^{\prime}, 3^{\prime} \mathrm{a}}=17.2, J_{1^{\prime} \mathrm{a}, 3^{\prime} \mathrm{a}}=J_{1^{\prime} \mathrm{b}, 3^{\prime} \mathrm{a}}=J_{3^{\prime} \mathrm{a}, 3^{\prime} \mathrm{a}}=1.4\right), 5.21(\mathrm{dq}, 1$ $\left.\mathrm{H}, \mathrm{H}-3^{\prime} \mathrm{b}, J_{2^{\prime}, 3^{\prime} \mathrm{b}}=10.3, J_{1^{\prime} \mathrm{a}, 3^{\prime} \mathrm{b}}=J_{1^{\prime} \mathrm{b}, 3^{\prime} \mathrm{b}}=J_{3^{\prime} \mathrm{a}, 3^{\prime} \mathrm{a}}=1.4\right), 4.57(\mathrm{~d}, 1 \mathrm{H}, \mathrm{H}-2), 4.28(\mathrm{td}, 1 \mathrm{H}, \mathrm{H}-$ $\left.4, J_{3,4}=3.4, J_{4,5 \mathrm{a}}=J_{4,5 \mathrm{~b}}=6.7\right), 4.14\left(\mathrm{ddt}, 1 \mathrm{H}, \mathrm{H}-1^{\prime} \mathrm{a}, J_{1^{\prime} \mathrm{a}, 1^{\prime} \mathrm{b}}=12.8, J_{1^{\prime} \mathrm{a}, 2^{\prime}}=5.3, J_{1^{\prime} \mathrm{a}, 3^{\prime} \mathrm{a}}=J_{1^{\prime} \mathrm{a}, 3^{\prime} \mathrm{b}}\right.$ $=1.4), 3.98\left(\mathrm{ddt}, 1 \mathrm{H}, \mathrm{H}-1^{\prime} \mathrm{b}, J_{1^{\prime} \mathrm{b}, 2^{\prime}}=5.9, J_{1^{\prime} \mathrm{b}, 3^{\prime} \mathrm{a}}=J_{1^{\prime} \mathrm{b}, 3^{\prime} \mathrm{b}}=1.4\right), 3.88(\mathrm{~d}, 1 \mathrm{H}, \mathrm{H}-3), 3.58-$ 3.45 (m, 2 H, H-5a, H-5b, $\left.J_{5 \mathrm{a}, 5 \mathrm{~b}}=12.4\right), 1.48$ (s, $3 \mathrm{H}, \mathrm{CH}_{3}, i$-Pr), 1.30 (s, $3 \mathrm{H}, \mathrm{CH}_{3}, i$-Pr) ppm. ${ }^{13} \mathrm{C} \mathrm{NMR}\left(\mathrm{CDCl}_{3}, 400 \mathrm{MHz}\right): \delta=133.7\left(\mathrm{C}-2^{\prime}\right), 118.0\left(\mathrm{C}-3^{\prime}\right), 111.9(\mathrm{Cq}, i-\mathrm{Pr}), 105.1$ 
(C-1), 82.2 (C-2), 81.4 (C-3), 78.8 (C-4), 71.0 (C-1'), 49.1 (C-5), 26.9 ( $\mathrm{CH}_{3}, i$-Pr), 26.3 $\left(\mathrm{CH}_{3}, i\right.$-Pr) ppm. HRMS: calcd for $\mathrm{C}_{11} \mathrm{H}_{17} \mathrm{~N}_{3} \mathrm{O}_{4}[\mathrm{M}+\mathrm{H}]^{+}$256.1292, found 256.1299.

4.1.5. General procedures for the reduction-guanidinylation of azido sugars.

Method A: To a solution of azido sugar $(0.13 \mathrm{mmol})$ in AcOEt $(3 \mathrm{~mL})$ under nitrogen atmosphere, $N, N^{\prime}$-bis(tert-butoxycarbonyl)- $N^{\prime \prime}$-triflylguanidine (51 mg, $0.13 \mathrm{mmol}$ ), $10 \%$ $\mathrm{Pd} / \mathrm{C}$ (spatula tip, approx. 20\% w/w) and $N, N$-diisopropylethylamine (DIPEA, 1.5 equiv., $0.03 \mathrm{~mL}, 0.2 \mathrm{mmol}$ ) were added. Three vacuum/nitrogen purge cycles were applied, and the mixture was then left stirring under hydrogen atmosphere overnight. The mixture was filtered over a short plug of Celite and the Celite pad was washed twice with AcOEt. The filtrate was concentrated under reduce pressure and the crude residue was subjected to column chromatography.

Method B: To a solution of azido sugar $(0.26 \mathrm{mmol})$ in $\mathrm{THF} / \mathrm{H}_{2} \mathrm{O}(2.8 \mathrm{~mL}, 13: 1)$, triphenylphosphane ( 2 equiv., $140 \mathrm{mg}, 0.52 \mathrm{mmol}$ ) was added and the mixture was stirred at room temperature for $4 \mathrm{~h}$. The solvents were evaporated, and the crude residue was dried under vacuum. The residue was then dissolved in AcOEt $(3.5 \mathrm{~mL})$ and to the resulting solution, under nitrogen atmosphere, $N, N^{\prime}$-bis(tert-butoxycarboyl)- $N^{\prime \prime}$ triflylguanidine (102 mg, $0.26 \mathrm{mmol}$ ) and DIPEA (2 equiv., $0.09 \mathrm{~mL}, 0.52 \mathrm{mmol}$ ) were added. The solution was stirred at room temp. for $45 \mathrm{~min}$ and it was then concentrated under reduced pressure (unless otherwise stated). The crude residue was subjected to column chromatography.

4.1.5.1. 5-[ $\left[N^{\prime}, N^{\prime \prime}\right.$-bis(tert-butoxycarbonyl)]guanidino-5-deoxy-1,2-O-isopropylidene-3$O$-propyl- $\alpha$-D-xylofuranose (16)

Obtained according to the general procedure for reduction-guanidinylation (method A), starting from starting from 5-azido-1,2- $O$-isopropylidene-3- $O$-propargyl- $\alpha$-Dxylofuranose $(13,150 \mathrm{mg}, 0.59 \mathrm{mmol})$ and using $N, N^{\prime}$-bis(tert-butoxycarboyl)- $N{ }^{\prime \prime}$ triflylguanidine (232 mg, $0.59 \mathrm{mmol})$ and DIPEA $(0.15 \mathrm{~mL}, 0.89 \mathrm{mmol})$. Purification by column chromatography (AcOEt/hexane 1:10) afforded $16(168 \mathrm{mg}, 60 \%$ ) as a yellow oil. $[\alpha]_{D}^{20}=-16\left(\mathrm{c}=1\right.$, in $\left.\mathrm{CH}_{2} \mathrm{Cl}_{2}\right) .{ }^{1} \mathrm{H} \mathrm{NMR}\left(\mathrm{CDCl}_{3}, 400 \mathrm{MHz}\right): \delta=11.45(\mathrm{~s}, 1 \mathrm{H}, \mathrm{NH})$, 8.60 (br.s, $1 \mathrm{H}, \mathrm{NH}$ ), 5.91 (d, $1 \mathrm{H}, \mathrm{H}-1, J_{1,2}=3.8$ ), 4.54 (d, $\left.1 \mathrm{H}, \mathrm{H}-2\right), 4.34$ (ddd, $1 \mathrm{H}, \mathrm{H}-$ 4), $3.88\left(\mathrm{dt}, 1 \mathrm{H}, \mathrm{H}-5 \mathrm{a}, J_{5 \mathrm{a}, 5 \mathrm{~b}}=13.8, J_{4,5 \mathrm{a}}=J_{5 \mathrm{a}, \mathrm{N} H}=6.0\right), 3.79$ (d, $\left.1 \mathrm{H}, \mathrm{H}-3, J_{3,4}=3.6\right), 3.65$ $\left(\mathrm{ddd}, 1 \mathrm{H}, \mathrm{H}-5 \mathrm{~b}, J_{4,5 \mathrm{~b}}=6.8, J_{5 \mathrm{~b}, \mathrm{~N} H}=4.9\right), 3.55\left(\mathrm{dt}, 1 \mathrm{H}, \mathrm{H}-1^{\prime} \mathrm{a}, J_{1^{\prime} \mathrm{a}, 1^{\prime} \mathrm{b}}=8.8, J_{1^{\prime} \mathrm{a}, \mathrm{CH} 2-2^{\prime}}=\right.$ 6.7), 3.38 (dt, $\left.1 \mathrm{H}, \mathrm{H}-1^{\prime} \mathrm{b}, J_{1^{\prime} \mathrm{b}, \mathrm{CH} 2-2^{\prime}}=6.7\right), 1.66-1.53$ (m, $\left.2 \mathrm{H}, \mathrm{CH}_{2}-2^{\prime}\right), 1.52$ (s, $3 \mathrm{H}, \mathrm{CH}_{3}$, $i$-Pr), 1.48, $1.47\left(2 \mathrm{~s}, 18 \mathrm{H}, 6 \times \mathrm{CH}_{3}, 2 \times \mathrm{Boc}\right), 1.30$ (s, $3 \mathrm{H}, \mathrm{CH}_{3}, i$-Pr), 0.9 (t, $3 \mathrm{H}, \mathrm{CH}_{3}-$ $\left.3^{\prime}, \mathrm{J}=7.4\right) \mathrm{ppm} .{ }^{13} \mathrm{C} \mathrm{NMR}\left(\mathrm{CDCl}_{3}, 400 \mathrm{MHz}\right): \delta=163.6(\mathrm{CO},=\mathrm{NBoc}), 156.4(\mathrm{Cq}, \mathrm{GN})$, 152.9 (CO, NHBoc), 111.5 (Cq, $i$-Pr), 105.2 (C-1), 83.0, 82.9 (C-3, Cq, Boc), 82.2 (C2), 79.2 (Cq, Boc), 78.0 (C-4), 72.0 (C-1'), 39.3 (C-5), 28.3, 28.1 (6 × $\left.\mathrm{CH}_{3}, \mathrm{Boc}\right), 26.9$ 
$\left(\mathrm{CH}_{3}, i\right.$-Pr), $26.3\left(\mathrm{CH}_{3}, i\right.$-Pr), $22.9\left(\mathrm{C}-2^{\prime}\right), 10.6\left(\mathrm{C}-3^{\prime}\right)$ ppm. HRMS: calcd for $\mathrm{C}_{22} \mathrm{H}_{39} \mathrm{~N}_{3} \mathrm{O}_{8}$ $[M+\mathrm{H}]^{+}$474.2810, found 474.2812.

4.1.5.2. 3-O-Allyl-5-[ $\quad N^{\prime}, N^{\prime \prime}$-bis(tert-butoxycarbonyl)]guanidino-5-deoxy-1,2-Oisopropylidene- $\alpha$-D-xylofuranose (17)

Obtained according to the general procedure for reduction-guanidinylation (method B), starting from 3-O-allyl-5-azido-5-deoxy-1,2-O-isopropylidene- $\alpha$-D-xylofuranose (12, $60 \mathrm{mg}, 0.235 \mathrm{mmol})$ and using triphenylphosphane (123 mg, $0.47 \mathrm{mmol}), N, N^{\prime}$-bis (tertbutoxycarboyl)- $N$ "-triflylguanidine (92 $\mathrm{mg}, 0.235 \mathrm{mmol})$ and DIPEA (0.47 mmol, 0.08 $\mathrm{mL}$ ). Purification by column chromatography (AcOEt/hexane 1:8) afforded 17 (98 mg, $88 \%)$ as a colorless oil. $[\alpha]_{D}^{20}=-12\left(\mathrm{c}=1\right.$, in $\left.\mathrm{CH}_{2} \mathrm{Cl}_{2}\right) .{ }^{1} \mathrm{H} \mathrm{NMR}\left(\mathrm{CDCl}_{3}, 400 \mathrm{MHz}\right): \delta=$ 8.60 (br.s, $1 \mathrm{H}, \mathrm{NH}$ ), $\delta=5.96-5.82$ (m, $2 \mathrm{H}, \mathrm{H}-1, \mathrm{H}-2^{\prime},{ }^{3} J_{1,2}=3.8$ ), 5.27 (dq, $1 \mathrm{H}, \mathrm{H}-3$ 'a, $\left.J_{2^{\prime}, 3^{\prime} \mathrm{a}}=17.3, J_{1^{\prime} \mathrm{a}, 3^{\prime} \mathrm{a}}=J_{1^{\prime} \mathrm{b}, 3^{\prime} \mathrm{a}}=J_{3^{\prime} \mathrm{a}, 3^{\prime} \mathrm{a}}=1.4\right), 5.19\left(\mathrm{dq}, 1 \mathrm{H}, \mathrm{H}-3^{\prime} \mathrm{b}, J_{2^{\prime}, 3^{\prime} \mathrm{b}}=10.3, J_{1^{\prime} \mathrm{a}, 3^{\prime} \mathrm{b}}=J_{1^{\prime} \mathrm{b}, 3^{\prime} \mathrm{b}}\right.$ $\left.=J_{3^{\prime} \mathrm{a}, 3^{\prime} \mathrm{a}}=1.4\right), 4.56(\mathrm{~d}, 1 \mathrm{H}, \mathrm{H}-2), 4.34(\mathrm{ddd}, 1 \mathrm{H}, \mathrm{H}-4), 4.13\left(\mathrm{ddt}, 1 \mathrm{H}, \mathrm{H}-1^{\prime} \mathrm{a}, J_{1^{\prime} \mathrm{a}, 1^{\prime} \mathrm{b}}=\right.$ 12.6, $\left.J_{1^{\prime} \mathrm{a}, 2^{\prime}}=5.4, J_{1^{\prime} \mathrm{a}, 3^{\prime} \mathrm{a}}=J_{1^{\prime} \mathrm{a}, 3^{\prime} \mathrm{b}}=1.4\right), 3.98\left(\mathrm{ddt}, 1 \mathrm{H}, \mathrm{H}-1^{\prime} \mathrm{b}, J_{1^{\prime} \mathrm{b}, 2^{\prime}}=6.0, J_{1^{\prime} \mathrm{b}, 3^{\prime} \mathrm{a}}=J_{1^{\prime} \mathrm{b}, 3^{\prime} \mathrm{b}}=\right.$ 1.4), 3.92-3.82 (m, 2 H, H-3, H-5a, $J_{3,4}=3.1$ ), 3.64 (ddd, $1 \mathrm{H}, \mathrm{H}-5 \mathrm{~b}, J_{5 \mathrm{a}, 5 \mathrm{~b}}=13.4, J_{4,5 \mathrm{~b}}=$ 7.2, $\left.J_{5 \mathrm{~b}, \mathrm{~N} H}=4.5\right), 1.52\left(\mathrm{~s}, 3 \mathrm{H}, \mathrm{CH}_{3}, i-\mathrm{Pr}\right), 1.48,1.47\left(2 \mathrm{~s}, 18 \mathrm{H}, 6 \times \mathrm{CH}_{3}, 2 \times \mathrm{Boc}\right), 1.30$ (s, $3 \mathrm{H}, \mathrm{CH}_{3}, i$-Pr) ppm. ${ }^{13} \mathrm{C} \mathrm{NMR}\left(\mathrm{CDCl}_{3}, 400 \mathrm{MHz}\right): \delta=163.6(\mathrm{CO},=\mathrm{NBoc}), 156.5$ (Cq, GN), 153.0 (CO, NHBoc), 133.9 (C-2'), 118.1 (C-3'), 111.7 (Cq, $i$-Pr), 105.2 (C-1), 83.1 (Cq, Boc), 82.4, 82.1 (C-2, C-3,), 79.4 (Cq, Boc), 78.1 (C-4), 71.1 (C-1'), 39.5 (C5), 28.4, $28.2\left(6 \times \mathrm{CH}_{3}\right.$, Boc), $26.8\left(\mathrm{CH}_{3}, i\right.$ - $\left.\mathrm{Pr}\right), 26.3\left(\mathrm{CH}_{3}, i\right.$-Pr $)$ ppm. HRMS: calcd for $\mathrm{C}_{22} \mathrm{H}_{37} \mathrm{~N}_{3} \mathrm{O}_{8}[M+\mathrm{H}]^{+} 472.2653$, found 472.2655 .

4.1.5.3. 5-[ $\left[N^{\prime}, N^{\prime \prime}\right.$-bis(tert-butoxycarbonyl)]guanidino-5-deoxy-1,2-O-isopropylidene-3$O$-propargyl- $\alpha$-D-xylofuranose (18)

Obtained according to the general procedure for reduction-guanidinylation (method B), starting from 5-azido-5-deoxy-1,2- $O$-isopropylidene-3- $O$-propargyl- $\alpha$-Dxylofuranose $(13,65 \mathrm{mg}, 0.26 \mathrm{mmol})$ and using triphenylphosphane (140 $\mathrm{mg}, 0.52$ mmol), $N, N^{\prime}$-bis(tert-butoxycarboyl)- $N^{\prime \prime}$-triflylguanidine (102 $\left.\mathrm{mg}, 0.26 \mathrm{mmol}\right)$ and DIPEA (0.09 mL, $0.52 \mathrm{mmol})$. Purification by column chromatography (AcOEt/hexane 1:8) afforded $18(115 \mathrm{mg}, 95 \%)$ as a colorless oil. $[\alpha]_{D}^{20}=-13\left(\mathrm{c}=1\right.$, in $\left.\mathrm{CH}_{2} \mathrm{Cl}_{2}\right)$. ${ }^{1} \mathrm{H} \mathrm{NMR}$ $\left(\mathrm{CDCl}_{3}, 400 \mathrm{MHz}\right): \delta=8.59$ (br.s, $\left.1 \mathrm{H}, \mathrm{NH}\right), 5.92$ (d, H-1, $\left.{ }^{3} J_{1,2}=3.7\right), 4.65$ (d, $1 \mathrm{H}, \mathrm{H}-2$ ), 4.37 (ddd, $1 \mathrm{H}, \mathrm{H}-4), 4.29$ (dd, part A of ABX system, H-1'a, $J_{1^{\prime} \mathrm{a}, 1^{\prime} \mathrm{b}}=16.0, J_{1^{\prime} \mathrm{a}, 3^{\prime}}=2.3$ ), $4.23\left(\mathrm{dd}\right.$, part B of ABX system, H-1'b, $\left.J_{1^{\prime} \mathrm{b}, 3^{\prime}}=2.3\right), 4.10\left(\mathrm{~d}, 1 \mathrm{H}, \mathrm{H}-3, J_{3,4}=3.1\right), 3.93$ $\left(\mathrm{ddd}, 1 \mathrm{H}, \mathrm{H}-5 \mathrm{a}, J_{5 \mathrm{a}, 5 \mathrm{~b}}=13.8, J_{4,5 \mathrm{a}}=6.4, J_{5 \mathrm{a}, \mathrm{NH}}=5.2\right.$ ), 3.59 (ddd, $1 \mathrm{H}, \mathrm{H}-5 \mathrm{~b}, J_{4,5 \mathrm{~b}}=7.2$, $\left.J_{5 \mathrm{~b}, \mathrm{~N} H}=4.6\right), 2.47\left(\mathrm{t}, 1 \mathrm{H}, \mathrm{H}-3^{\prime}, J_{1^{\prime} \mathrm{a}, 3^{\prime}}=J_{1^{\prime} \mathrm{b}, 3^{\prime}}=2.3\right), 1.49,1.48\left(2 \mathrm{~s}, 21 \mathrm{H}, 6 \times \mathrm{CH}_{3}, 2 \times\right.$ Boc, $\mathrm{CH}_{3}, i$-Pr), 1.31 (s, $3 \mathrm{H}, \mathrm{CH}_{3}, i$-Pr) ppm. ${ }^{13} \mathrm{C} \mathrm{NMR}\left(\mathrm{CDCl}_{3}, 400 \mathrm{MHz}\right): \delta=163.6$ (CO, =NBoc), 156.5 (Cq, GN), 153.0 (CO, NHBoc), 111.9 (Cq, $i$-Pr), $105.1(\mathrm{C}-1), 83.2$ (Cq, Boc), 82.3, 81.9 (C-2, C-3), 79.4 (Cq, Boc), 79.0 (C-2'), 78.2 (C-4), 75.6 (C-3'), 57.6 $\left(\mathrm{C}-1^{\prime}\right), 39.4$ (C-5), 28.4, $28.2\left(6 \times \mathrm{CH}_{3}, \mathrm{Boc}\right), 26.8\left(\mathrm{CH}_{3}, i\right.$-Pr $), 26.4\left(\mathrm{CH}_{3}, i\right.$-Pr $) \mathrm{ppm}$. 
HRMS: calcd for $\mathrm{C}_{22} \mathrm{H}_{35} \mathrm{~N}_{3} \mathrm{O}_{8}[M+\mathrm{H}]^{+} 470.2497$, found 470.2494. calcd for $\mathrm{C}_{22} \mathrm{H}_{35} \mathrm{~N}_{3} \mathrm{O}_{8}$ $[M+\mathrm{Na}]^{+}$492.2316, found 492.2307 .

\subsubsection{5-[ $N^{\prime}, N^{\prime \prime}$-bis(tert-butoxycarbonyl)]guanidino-5-deoxy-3-O-dodecyl-1,2-O-} isopropylidene- $\alpha$-D-xylofuranose (19)

Obtained according to the general procedure for reduction-guanidinylation (method A), starting from starting from 5-azido-5-deoxy-3- $O$-dodecyl-1,2- $O$-isopropylidene- $\alpha$-Dxylofuranose (14, $50 \mathrm{mg}, 0.13 \mathrm{mmol}$ ) and using $N, N^{\prime}$-bis(tert-butoxycarboyl)- $N^{\prime \prime}$ triflylguanidine (51 mg, $0.13 \mathrm{mmol})$ and DIPEA $(0.03 \mathrm{~mL}, 0.2 \mathrm{mmol})$. Purification by column chromatography (AcOEt/petroleum ether 1:20) afforded 19 (67 mg, 86\%) as a colorless oil.

Alternatively, the title compound could be obtained through method B, starting from 14 (70 mg, $0.18 \mathrm{mmol}$ ), and using triphenylphosphane (96 mg, $0.37 \mathrm{mmol}$ ), $N, N^{\prime}$-bis $($ tertbutoxycarboyl)- $N^{\prime \prime}$-triflylguanidine $(71 \mathrm{mg}, 0.18 \mathrm{mmol})$ and DIPEA $(0.06 \mathrm{~mL}, 0.37$ $\mathrm{mmol})$, in $81 \%$ yield $(88 \mathrm{mg}) .[\alpha]_{D}^{20}=-15\left(\mathrm{c}=1\right.$, in $\left.\mathrm{CH}_{2} \mathrm{Cl}_{2}\right) .{ }^{1} \mathrm{H} \mathrm{NMR}\left(\mathrm{CDCl}_{3}, 400 \mathrm{MHz}\right)$ : $\delta=11.45$ (s, $1 \mathrm{H}, \mathrm{N} H), 8.57$ (br.s, $1 \mathrm{H}, \mathrm{N} H), 5.89$ (d, H-1, $\left.{ }^{3} J_{1,2}=3.6\right), 4.52$ (d, $\left.1 \mathrm{H}, \mathrm{H}-2\right)$, 4.32 (br. ddd, $1 \mathrm{H}, \mathrm{H}-4), 3.84$ (dt, $\left.1 \mathrm{H}, \mathrm{H}-5 \mathrm{a}, J_{5 \mathrm{a}, 5 \mathrm{~b}}=13.5, J_{4,5 \mathrm{a}}=J_{5 \mathrm{a}, \mathrm{NH}}=5.9\right), 3.76$ (d, 1 H, H-3, $J_{3,4}=2.9$ ), 3.69-3.49 (m, 2 H, H-5b, H-1'a), 3.43-3.33 (m, 1 H, H-1'b), 1.58-1.39 (m, $23 \mathrm{H}, \mathrm{CH}_{2}-2^{\prime}, 6 \times \mathrm{CH}_{3}, 2 \times$ Boc, $\mathrm{CH}_{3}, i$-Pr), 1.34-1.15 (m, $21 \mathrm{H}, \mathrm{CH}_{3}, i-\mathrm{Pr}, \mathrm{CH}_{2}-3^{\prime}$ to $\left.\mathrm{CH}_{2}-11^{\prime}\right), 0.84\left(\mathrm{t}, 3 \mathrm{H}, \mathrm{CH}_{3}-12^{\prime},{ }^{3} J=6.5\right) \mathrm{ppm} .{ }^{13} \mathrm{C} \mathrm{NMR}\left(\mathrm{CDCl}_{3}, 400 \mathrm{MHz}\right): \delta=163.6$ ( $C \mathrm{O},=\mathrm{NBoc}), 156.5(\mathrm{Cq}, \mathrm{GN}), 153.0$ (CO, NHBoc), 111.6 (Cq, $i$-Pr), $105.2(\mathrm{C}-1), 83.0$, 83.0 (C-3, Cq, Boc), 82.3 (C-2), 79.2 (Cq, Boc), 78.1 (C-4), 70.6 (C-1'), 39.4 (C-5), 32.0, 29.7, 29.7, 29.7, 29.6, 29.4 (C-2' to $\left.\mathrm{C}^{\prime} 9^{\prime}\right), 28.4,28.1\left(6 \times \mathrm{CH}_{3}, \mathrm{Boc}\right), 26.8\left(\mathrm{CH}_{3}, i\right.$ - $\left.\mathrm{Pr}\right)$, $26.3\left(\mathrm{CH}_{3}, i\right.$-Pr $), 26.2\left(\mathrm{C}-10^{\prime}\right), 22.8\left(\mathrm{C}-11^{\prime}\right), 14.2\left(\mathrm{C}-12^{\prime}\right)$ ppm. HRMS: calcd for $\mathrm{C}_{31} \mathrm{H}_{57} \mathrm{~N}_{3} \mathrm{O}_{8}[\mathrm{M}+\mathrm{H}]+600.4218$, found 600.4216 .

\subsubsection{3-O-Benzyl-5-[ $N^{\prime}, N^{\prime \prime}$-bis(tert-butoxycarbonyl)]guanidino-5-deoxy-1,2-O- isopropylidene- $\alpha$-D-xylofuranose (20)}

Obtained according to the general procedure for reduction-guanidinylation (method A), starting from starting from 5-azido-3- $O$-benzyl-5-deoxy-1,2- $O$-isopropylidene- $\alpha$-Dxylofuranose (15, $60 \mathrm{mg}, 0.2 \mathrm{mmol})$ and using $N, N^{\prime}$-bis(tert-butoxycarboyl)- $N^{\prime \prime}-$ triflylguanidine ( $77 \mathrm{mg}, 0.2 \mathrm{mmol})$ and DIPEA $(0.05 \mathrm{~mL}, 0.3 \mathrm{mmol})$. Purification by column chromatography (AcOEt/petroleum ether 1:20) afforded 20 (91 mg, 89\%) as a colorless oil.

Alternatively, the title compound could be obtained through method B, starting from 15 (60 mg, $0.2 \mathrm{mmol}$ ), and using triphenylphosphane (103 mg, $0.39 \mathrm{mmol}), N, N^{\prime}$-bis (tertbutoxycarboyl)- $N$ "-triflylguanidine $(77 \mathrm{mg}, 0.2 \mathrm{mmol})$ and DIPEA (0.07 mL, 0.39 $\mathrm{mmol})$, in $83 \%$ yield $(85 \mathrm{mg}) .[\alpha]_{D}^{20}=-23\left(\mathrm{c}=1\right.$, in $\left.\mathrm{CH}_{2} \mathrm{Cl}_{2}\right) .{ }^{1} \mathrm{H} \mathrm{NMR}\left(\mathrm{CDCl}_{3}, 400 \mathrm{MHz}\right)$ : $\delta=8.63$ (br.s, $1 \mathrm{H}, \mathrm{NH}$ ), 7.39-7.26 (m, $5 \mathrm{H}, \mathrm{CH}, \mathrm{Ph}$ ), 5.95 (d, H-1, $\left.{ }^{3} J_{1,2}=3.8\right), 4.67$ (d, part A of AB system, $1 \mathrm{H}, \mathrm{H}$-a from $\left.\mathrm{CH}_{2} \mathrm{Ph},{ }^{2} J_{\mathrm{a}, \mathrm{b}}=11.9\right), 4.62(\mathrm{~d}, 1 \mathrm{H}, \mathrm{H}-2), 4.52$ (d, part 
B of $\mathrm{AB}$ system, $1 \mathrm{H}, \mathrm{H}-\mathrm{b}$ from $\mathrm{CH}_{2} \mathrm{Ph}$ ), 4.34 (ddd, $\left.1 \mathrm{H}, \mathrm{H}-4\right), 3.95$ (d, $1 \mathrm{H}, \mathrm{H}-3, J_{3,4}=$ 3.5), 3.88 (dd, part A of ABX system, $\left.1 \mathrm{H}, \mathrm{H}-5 \mathrm{a}, J_{5 \mathrm{a}, 5 \mathrm{~b}}=14.1, J_{4,5 \mathrm{a}}=4.8\right), 3.64$ (dd, part B of ABS system, $\left.1 \mathrm{H}, \mathrm{H}-5 \mathrm{~b}, J_{4,5 \mathrm{~b}}=7.2\right), 1.51-1.42\left(\mathrm{~m}, 21 \mathrm{H}, 6 \times \mathrm{CH}_{3}, 2 \times \mathrm{Boc}, \mathrm{CH}_{3}, i\right.$ $\mathrm{Pr}), 1.30$ (s, $3 \mathrm{H}, \mathrm{CH}_{3}, i$-Pr) ppm. ${ }^{13} \mathrm{C} \mathrm{NMR}\left(\mathrm{CDCl}_{3}, 400 \mathrm{MHz}\right): \delta=163.3(\mathrm{CO},=\mathrm{NBoc})$, 156.5 (Cq, GN), 153.1 (CO, NHBoc), 137.2 (Cq, Ph), 128.6, 128.1, 128.0 (CH, Ph), 112.0 (Cq, $i$-Pr), 105.1 (C-1), 83.4 (Cq, Boc), 82.2, 82.2 (C-2, C-3), 79.7 (Cq, Boc), 78.2 (C4), $72.0\left(\mathrm{CH}_{2} \mathrm{Ph}\right), 39.4(\mathrm{C}-5), 28.3,28.1\left(6 \times \mathrm{CH}_{3}, \mathrm{Boc}\right), 26.8\left(\mathrm{CH}_{3}, i-\mathrm{Pr}\right), 26.2\left(\mathrm{CH}_{3}, i-\right.$ Pr) ppm. HRMS: calcd for $\mathrm{C}_{26} \mathrm{H}_{39} \mathrm{~N}_{3} \mathrm{O}_{8}[M+\mathrm{H}]^{+}$522.2810, found 522.2810.

\subsubsection{3-O-(1-Benzyl-1H-1,2,3-triazol-4-yl)methyl-5-[ $N^{\prime}, N^{\prime \prime}$-bis $($ tert-} butoxycarbonyl)]guanidino-5-deoxy-1,2- $O$-isopropylidene- $\alpha$-D-xylofuranose (24) and 3-O-(1-Benzyl-5-iodo-1H-1,2,3-triazol-4-yl)methyl-5-[ $N^{\prime}, N^{\prime \prime}$-bis(tertbutoxycarbonyl)]guanidino-5-deoxy-1,2- $O$-isopropylidene- $\alpha$-D-xylofuranose (25)

Compound 24 was obtained according to the procedure for reduction-guanidinylation (method B), starting from 5-[ $N^{\prime}, N^{\prime \prime}$-bis(tert-butoxycarbonyl) $]$ guanidino-5-deoxy-1,2-Oisopropylidene-3-O-propargyl- $\alpha$-D-xylofuranose $(\mathbf{1 8}, 251 \mathrm{mg}, 0.65 \mathrm{mmol})$ and using triphenylphosphane $\quad(341 \mathrm{mg}, \quad 1.3 \mathrm{mmol}), \quad N, N^{\prime}$-bis(tert-butoxycarboyl)- $N^{\prime \prime}$ triflylguanidine $(127 \mathrm{mg}, 0.65 \mathrm{mmol})$ and DIPEA (0.08 $\mathrm{mL}, 0.46 \mathrm{mmol})$. The guanidinylation step was completed within $2 \mathrm{~h}$; then the mixture was diluted with AcOEt and washed with water $(2 \times)$. The organic phase was dried with anhydrous $\mathrm{MgSO}_{4}$, filtered, the solvent was evaporated under vacuum and the residue was purified by column chromatography (AcOEt/hexane, 1:1) afforded 24 (328 mg, 84\%) as a colorless oil.

In addition, 24 could be accessed, along with 25, starting from 18 and using the following procedure:

To a solution of 5-[ $\left[N^{\prime}, N^{\prime \prime}\right.$-bis(tert-butoxycarbonyl) $]$ guanidino-5-deoxy-1,2-Oisopropylidene-3- $O$-propargyl- $\alpha$-D-xylofuranose $(\mathbf{1 8}, 250 \mathrm{mg}, 0.53 \mathrm{mmol}$ ) in AcOEt (10 $\mathrm{mL})$ under nitrogen atmosphere, benzyl azide $(1.7 \mathrm{~mL}, 12.8 \mathrm{mmol})$ and CuI/Amberlyst A-21 (0.5 mmol.g-1, $0.1 \mathrm{mmol} \mathrm{CuI,} 200 \mathrm{mg}$ ) were added. The mixture was stirred at room temperature for $4 \mathrm{~d}$. The catalyst was filtered off, the solvent was evaporated, and the crude residue was subjected to column chromatography (AcOEt/hexane, 1:3) to afford $\mathbf{2 4}$ (121 mg, 38\%) and 25 (40 mg, 10\%) as yellow oil.

Compound 25 could be solely obtained by reacting $18(34 \mathrm{mg}, 0.072 \mathrm{mmol})$ in $\mathrm{CH}_{2} \mathrm{Cl}_{2}(10 \mathrm{~mL})$ with benzyl azide $(0.05 \mathrm{~mL}, 0.4 \mathrm{mmol})$ and $\mathrm{CuI}(14 \mathrm{mg}, 0.072 \mathrm{mmol})$ in the presence of DMAP $(2.7 \mathrm{mg}, 0.022 \mathrm{mmol})$. The mixture was stirred at $30^{\circ} \mathrm{C}$ for $72 \mathrm{~h}$. It was then diluted with $\mathrm{CH}_{2} \mathrm{Cl}_{2}(10 \mathrm{ml})$ and washed with $1 \mathrm{M} \mathrm{HCl}(2 \times 2 \mathrm{ml})$ and water ( $2 \mathrm{ml}$ ). The organic phase was dried with anhydrous $\mathrm{MgSO}_{4}$, filtered, and the solvent was evaporated under vacuum. The residue was purified by column chromatography (AcOEt/hexane 1:4) to afford 25 (35 mg, 66\%). 
Data for 24: $[\alpha]_{D}^{20}=-65\left(\mathrm{c}=1\right.$, in $\left.\mathrm{CH}_{2} \mathrm{Cl}_{2}\right) .{ }^{1} \mathrm{H} \mathrm{NMR}\left(\mathrm{CDCl}_{3}, 400 \mathrm{MHz}\right): \delta=11.46(\mathrm{~s}, 1$ $\mathrm{H}, \mathrm{NH}$ ), 8.57 (br. t, $1 \mathrm{H}, \mathrm{NH}$ ), 7.58 (s, $1 \mathrm{H}, \mathrm{H}-3^{\prime}$ ), 7.42-7.24 (m, $5 \mathrm{H}, \mathrm{CH}, \mathrm{Ph}$ ), 5.89 (d, $\left.\mathrm{H}-1,{ }^{3} J_{1,2}=3.7\right), 5.55,5.50\left(2 \mathrm{~d}, \mathrm{AB}\right.$ system, $\left.2 \mathrm{H}, \mathrm{CH}_{2} \mathrm{Ph},{ }^{2} J_{\mathrm{a}, \mathrm{b}}=15.2\right), 4.77$ (d, $1 \mathrm{H}$, part A of AB system, H-1'a, $\left.{ }^{2} J_{1^{\prime} \mathrm{a}, 1^{\prime} \mathrm{b}}=11.9\right), 4.67-4.60$ (m, $2 \mathrm{H}, \mathrm{H}-1$ 'b, H-2), 4.34 (ddd, $1 \mathrm{H}$, $\mathrm{H}-4), 4.00$ (d, $1 \mathrm{H}, \mathrm{H}-3, J_{3,4}=3.1$ ), $3.83\left(\mathrm{dt}, 1 \mathrm{H}, \mathrm{H}-5 \mathrm{a}, J_{5 \mathrm{a}, 5 \mathrm{~b}}=13.7, J_{4,5 \mathrm{a}}=J_{5 \mathrm{a}, \mathrm{N} H}=5.8\right.$ ), 3.59 (ddd, $\left.1 \mathrm{H}, \mathrm{H}-5 \mathrm{~b}, J_{4,5 \mathrm{~b}}=7.2, J_{5 \mathrm{~b}, \mathrm{NH}}=5.0\right), 1.48,1.45\left(2 \mathrm{~s}, 21 \mathrm{H}, 6 \times \mathrm{CH}_{3}, 2 \times \mathrm{Boc}\right.$, $\mathrm{CH}_{3}, i$-Pr), $1.30\left(\mathrm{~s}, 3 \mathrm{H}, \mathrm{CH}_{3}, i\right.$-Pr) ppm. ${ }^{13} \mathrm{C} \mathrm{NMR}\left(\mathrm{CDCl}_{3}, 400 \mathrm{MHz}\right): \delta=163.6(\mathrm{CO}$, $=\mathrm{NBoc}), 156.4(\mathrm{Cq}, \mathrm{GN}), 153.0$ (CO, NHBoc), 144.7 (C-2'), 134.6 (Cq, Ph), 129.3, 128.9, 128.2 (CH, Ph), 122.9 (C-3'), 111.8 (Cq, i-Pr), 105.2 (C-1), 83.2 (Cq, Boc), 82.8 (C-3), 82.1 (C-2), 79.4 (Cq, Boc), 78.0 (C-4), 63.8 (C-1'), $54.3\left(\mathrm{CH}_{2} \mathrm{Ph}\right), 39.4(\mathrm{C}-5)$, 28.4, $28.2\left(6 \times \mathrm{CH}_{3}, \mathrm{Boc}\right), 26.8\left(\mathrm{CH}_{3}, i\right.$-Pr $), 26.3\left(\mathrm{CH}_{3}, i\right.$-Pr $)$ ppm. HRMS: calcd for $\mathrm{C}_{29} \mathrm{H}_{42} \mathrm{~N}_{6} \mathrm{O}_{8}[M+\mathrm{H}]^{+}$603.3137, found 603.3146.

Data for 25: $[\alpha]_{D}^{20}=-27\left(\mathrm{c}=1\right.$, in $\left.\mathrm{CH}_{2} \mathrm{Cl}_{2}\right) .{ }^{1} \mathrm{H} \mathrm{NMR}\left(\mathrm{CDCl}_{3}, 400 \mathrm{MHz}\right): \delta=11.42(\mathrm{~s}, 1$ $\mathrm{H}, \mathrm{NH}$ ), 8.55 (br. t, $1 \mathrm{H}, \mathrm{NH}$ ), 7.40-7.23 (m, $5 \mathrm{H}, \mathrm{CH}, \mathrm{Ph}$ ), 5.91 (br. d, H-1), 5.58 (br. s, $2 \mathrm{H}, \mathrm{CH}_{2} \mathrm{Ph}$ ), 4.73-4.65 (m, $2 \mathrm{H}, \mathrm{H}-1$ 'a, H-2), 4.61 (d, $1 \mathrm{H}$, part B of AB system, H-1'b, ${ }^{2} J_{1^{\prime} \mathrm{a}, 1^{\prime} \mathrm{b}}=11.9$ ), 4.38 (br.ddd, $\left.1 \mathrm{H}, \mathrm{H}-4\right), 4.03$ (br.d, $\left.1 \mathrm{H}, \mathrm{H}-3\right), 3.93$ (br.ddd, $1 \mathrm{H}, \mathrm{H}-5 \mathrm{a}$, $\left.J_{5 \mathrm{a}, 5 \mathrm{~b}}=13.8\right), 3.57\left(\mathrm{ddd}, 1 \mathrm{H}, \mathrm{H}-5 \mathrm{~b}, J_{4,5 \mathrm{~b}}=7.2, J_{5 \mathrm{~b}, \mathrm{~N} H}=5.0\right), 1.48,1.47(2 \mathrm{~s}, 21 \mathrm{H}, 6 \times$ $\mathrm{CH}_{3}, 2 \times$ Boc, $\left.\mathrm{CH}_{3}, i-\mathrm{Pr}\right), 1.30\left(\mathrm{~s}, 3 \mathrm{H}, \mathrm{CH}_{3}, i-\mathrm{Pr}\right) \mathrm{ppm} .{ }^{13} \mathrm{C} \mathrm{NMR}\left(\mathrm{CDCl}_{3}, 400 \mathrm{MHz}\right): \delta$ $\left.=163.6(\mathrm{CO},=\mathrm{NBoc}), 156.4(\mathrm{Cq}, \mathrm{GN}), 153.0(\mathrm{CO}, \mathrm{NHBoc}), 148.3(\mathrm{C}-2)^{\prime}\right), 134.2(\mathrm{Cq}$, $\mathrm{Ph}), 129.1,128.7,128.0(\mathrm{CH}, \mathrm{Ph}), 111.8$ (Cq, $i$-Pr), 105.2 (C-1), 83.1 (Cq, Boc), 82.6 (C-3), 82.3 (C-2), 80.8 (C-3'), 79.3 (Cq, Boc), 78.2 (C-4), $63.5\left(\mathrm{C}-1^{\prime}\right), 54.4\left(\mathrm{CH}_{2} \mathrm{Ph}\right), 39.8$ (C-5), 28.4, $28.2\left(6 \times \mathrm{CH}_{3}\right.$, Boc), $26.8\left(\mathrm{CH}_{3}, i\right.$-Pr $), 26.4\left(\mathrm{CH}_{3}, i\right.$-Pr $)$ ppm. HRMS: calcd for $\mathrm{C}_{29} \mathrm{H}_{41} \mathrm{IN}_{6} \mathrm{O}_{8}[M+\mathrm{H}]^{+} 729.2103$, found 729.2117 .

\subsubsection{5-Deoxy-5-(4- $\left\{\left[N^{\prime}, N^{\prime \prime}\right.\right.$-bis(tert-butoxycarbonyl) $]$ guanidino $\}$ methyl-1H-1,2,3-} triazol-1-yl)-3- $O$-dodecyl-1,2- $O$-isopropylidene- $\alpha$-D-xylofuranose (22)

To a solution of 5-(4-aminomethyl-1H-1,2,3-triazol-1-yl)-5-deoxy-3-O-dodecyl-1,2-Oisopropylidene- $\alpha$-d-xylofuranose $(\mathbf{2 1}, 11 \mathrm{mg}, 0.025 \mathrm{mmol})$ in AcOEt $(1 \mathrm{~mL}), N, N^{\prime}-$ bis(tert-butoxycarbonyl)- $N^{\prime \prime}$-triflylguanidine $(9.8 \mathrm{mg}, 0.026 \mathrm{mmol} \mathrm{mmol})$, and DIPEA $(0.01 \mathrm{~mL}, 0.057 \mathrm{mmol})$ were added and the solution was stirred at at room temperature under nitrogen atmosphere for $18 \mathrm{~h}$. The solvent was removed under reduced pressure. The residue was purified by column chromatography (AcOEt/hexane 1:6) to afford 22 (9.2 mg, 54\%) as a colorless oil. ${ }^{1} \mathrm{H} \mathrm{NMR}\left(\mathrm{CDCl}_{3}, 400 \mathrm{MHz}\right): \delta=11.46(\mathrm{~s}, 1 \mathrm{H}, \mathrm{NH})$, 8.79 (br. t, $1 \mathrm{H}, \mathrm{NH}-5$ ), 7.64 (s, $1 \mathrm{H}, \mathrm{H}-5), 5.94$ (d, H-1', ${ }^{3} J_{1^{\prime}, 2^{\prime}}=3.7$ ), 4.78-4.63 (m, $3 \mathrm{H}$, $\left.\mathrm{CH}_{2} \mathrm{~N}, \mathrm{H}-5^{\prime} \mathrm{a}, J_{\mathrm{a}, \mathrm{b}}=11.5, J_{\mathrm{a}, \mathrm{N} H}=5.0, J_{\mathrm{a}, \mathrm{N} H}=5.1\right), 4.59(\mathrm{~d}, 1 \mathrm{H}, \mathrm{H}-2), 3.84\left(\mathrm{~d}, 1 \mathrm{H}, \mathrm{H}-3^{\prime}\right.$, $J_{3^{\prime}, 4^{\prime}}=3.1$ ), 4.56-4.43 (m, 2 H, H-4', H-5'b), 3.68-3.58 (m, 1 H, H-1"a), 3.47-3.37 (m, 1 $\left.\mathrm{H}, \mathrm{H}-1{ }^{\prime \prime} \mathrm{b}\right), 1.63-1.53$ (m, $23 \mathrm{H}, \mathrm{CH}_{2}-2^{\prime \prime}, 6 \times \mathrm{CH}_{3}, 2 \times \mathrm{Boc} \mathrm{CH}_{3}, i$-Pr) $1.34-1.15$ (m, 21 $\mathrm{H}, \mathrm{CH}_{3}, i-\mathrm{Pr}, \mathrm{CH}_{2}-3$ " to $\left.\mathrm{CH}_{2}-11^{\prime \prime}\right), 0.87\left(\mathrm{t}, 3 \mathrm{H}, \mathrm{CH}_{3}-12^{\prime \prime},{ }^{3} \mathrm{~J}=6.5\right) \mathrm{ppm} .{ }^{13} \mathrm{C} \mathrm{NMR}\left(\mathrm{CDCl}_{3}\right.$, $400 \mathrm{MHz}): \delta=163.5$ (CO, =NBoc), 156.1 (Cq, GN), 153.1 (CO, NHBoc), 144.0 (C-4), 123.4 (C-5), 112.2 (Cq, $i$-Pr), 105.4 (C-1), 83.4 (Cq, Boc), 82.5, 82.1 (C-2, C-3), 79.6 (Cq, Boc), 79.0 (C-4), $70.7\left(\mathrm{C}-1^{\prime \prime}\right), 49.4\left(\mathrm{C}-5^{\prime}\right), 36.6\left(\mathrm{CH}_{2} \mathrm{~N}\right), 32.1,29.8,29.8,29.7,29.6$, 
29.5 (C-2" to C-9"), 28.4, $28.2\left(6 \times \mathrm{CH}_{3}, \mathrm{Boc}\right), 26.9\left(\mathrm{CH}_{3}, i-\mathrm{Pr}\right), 26.4\left(\mathrm{CH}_{3}, i-\mathrm{Pr}\right), 26.3$ $\left(\mathrm{C}-10^{\prime \prime}\right), 22.8\left(\mathrm{C}-11^{\prime \prime}\right), 14.3\left(\mathrm{C}-12^{\prime \prime}\right)$ ppm. HRMS: calcd for $\mathrm{C}_{34} \mathrm{H}_{60} \mathrm{~N}_{6} \mathrm{O}_{8}[\mathrm{M}+\mathrm{H}]+$ 681.4551, found 681.4557 .

4.1.7. General procedures for $t$-butoxycarbonyl group (Boc) and 1,2-O-acetonide removal

A solution of 5-[ $\left[N^{\prime}, N^{\prime \prime}\right.$-bis(Boc) $]$ guanidino-3- $O$-benzyl/dodecyl-1,2- $O$-isopropylidene- $\alpha$ D-xylofuranose $(0.15 \mathrm{mmol})$ in $\mathrm{TFA} / \mathrm{H}_{2} \mathrm{O} /$ triethylsilane $48: 1: 1(2 \mathrm{~mL})$ was stirred at room temperature under nitrogen atmosphere for $2 \mathrm{~h}$. The solvent was removed under reduced pressure. The residue was purified by column chromatography.

\subsubsection{5-[N'-(tert-butoxycarbonyl)]guanidino-5-deoxy-3-O-dodecyl-1,2-O-} isopropylidene- $\alpha$-D-xylofuranose (26)

Obtained according to the general procedure for $t$-butoxycarbonyl group (Boc) and 1,2-O-acetonide removal, starting from 5-[ $N^{\prime}, N^{\prime \prime}$-bis(tert-butoxycarbonyl)]guanidino-5deoxy-3-O-dodecyl-1,2- $O$-isopropylidene- $\alpha$-D-xylofuranose $(\mathbf{1 9}, 91 \mathrm{mg}, 0.15 \mathrm{mmol})$. Purification by column chromatography (dichloromethane/methanol 10:1) afforded 26 (23 mg, 33\%) as a colorless oil. ${ }^{1} \mathrm{H}$ NMR (MeOD, $\left.400 \mathrm{MHz}\right): 5.29$ (d, $1 \mathrm{H}, \mathrm{H}-1 \alpha,{ }^{3} J_{1,2}=$ 3.8), 5.15 (br. s, 0.9 H, H-1 $\beta$ ), 4.50-4.40 (m, H-4 $\beta, \mathrm{H}-4 \alpha$ ), 4.09-3.98 (m, 2.9 H, H-2 $\alpha$, H-2 $\beta^{*}, \mathrm{H}-3 \alpha$ ), 3.89 (dd, 0.9 H, H-3 $\beta$ ), 3.79-3.41 (m, 7.6 H, H-5a $\alpha$, H-5 b $\alpha$, H-5a $\beta$, H5 b $\left.\beta, \mathrm{H}-1^{\prime} \mathrm{a} \alpha, \mathrm{H}-1^{\prime} \mathrm{b} \alpha, \mathrm{H}-1^{\prime} \mathrm{a} \beta, \mathrm{H}-1^{\prime} \mathrm{b} \beta\right), 1.68-1.57$ (m, $\left.3.8 \mathrm{H}, \mathrm{CH}_{2}-2^{\prime} \alpha, \mathrm{CH}_{2}-2^{\prime} \beta\right), 1.57-$ 1.49 (br.s, $17.1 \mathrm{H}, 3 \times \mathrm{CH}_{3}$, Boc $\alpha, 3 \times \mathrm{CH}_{3}$, Boc $\beta$ ), 1.42-1.21 (br.s, $34.2 \mathrm{H}, \mathrm{CH}_{3}, \mathrm{CH}_{2}-$ $3^{\prime}$ to $\left.\mathrm{CH}_{2}-11^{\prime}, \alpha, \beta\right), 0.90$ (t, $\left.5.7 \mathrm{H}, \mathrm{CH}_{3}-12^{\prime}, \alpha, \beta,{ }^{3} J=6.8\right) .{ }^{13} \mathrm{C} \mathrm{NMR}(\mathrm{MeOD}, 400 \mathrm{MHz}$ ): $\delta=156.5(\mathrm{Cq}, \mathrm{GN}), 153.6,153.5(\mathrm{CO}, \mathrm{NHBoc})^{*}, 104.4(\mathrm{C}-1 \beta), 97.6(\mathrm{C}-1 \alpha), 86.2(\mathrm{C}-3$ $\beta), 85.8,85.7$ (Cq, Boc), 85.2 (C-3 $\alpha$ ), 80.1 (C-2 $\beta$ ), 79.7 (C-4 $\beta$ ), 77.3 (C-2 $\alpha), 76.4$ (C-4 $\alpha), 71.8,71.7\left(\mathrm{C}-1^{\prime}, \alpha, \beta\right), 43.4,42.8(\mathrm{C}-5 \alpha, \beta), 33.1,30.9,30.8,30.8,30.6,30.5$ (C-2' to $\left.\mathrm{C}-9^{\prime}, \alpha, \beta\right), 28.1\left(6 \times \mathrm{CH}_{3}\right.$, Boc, $\left.\alpha, \beta\right), 27.3,27.3\left(\mathrm{C}-10^{\prime}, \alpha, \beta\right), 23.8\left(\mathrm{C}-11^{\prime}, \alpha, \beta\right), 14.5(\mathrm{C}-$ $\left.12^{\prime}, \alpha, \beta\right)$ ppm. HRMS: calcd for $\mathrm{C}_{23} \mathrm{H}_{46} \mathrm{~N}_{3} \mathrm{O}_{6}[\mathrm{M}+\mathrm{H}]+460.3381$, found 460.3385 .

\subsubsection{3-O-Benzyl-5-guanidino-5-deoxy-1,2- $O$-isopropylidene- $\alpha$-D-xylofuranose (27)}

Obtained according to the general procedure for $t$-butoxycarbonyl group (Boc) and 1,2$O$-acetonide removal, starting from 3-O-benzyl-5-[ $N^{\prime}, N^{\prime \prime}$-bis $($ tertbutoxycarbonyl)]guanidino-5-deoxy-1,2- $O$-isopropylidene- $\alpha$-D-xylofuranose $\quad(\mathbf{2 0}, \quad 82$ $\mathrm{mg}, 0.157 \mathrm{mmol}$ ). Purification by column chromatography (AcOEt/methanol 10:1) afforded 27 (16 mg, 36\%) as a colorless oil. ${ }^{1} \mathrm{H}$ NMR (MeOD, $300 \mathrm{MHz}$ ): $\delta=7.46-7.25$ $(\mathrm{m}, 10 \mathrm{H}, \mathrm{CH}, \mathrm{Ph}, \alpha, \beta), 5.34\left(\mathrm{~d}, 1 \mathrm{H}, \mathrm{H}-1 \alpha,{ }^{3} J_{1,2(\alpha)}=4.2\right), 5.16\left(\mathrm{~d}, 1 \mathrm{H}, \mathrm{H}-1 \beta,{ }^{3} J_{1,2}(\beta)=\right.$ 1.5), 4.78, $4.74\left(2 \mathrm{~d}, 2 \times\right.$ part A of AB system, $2 \mathrm{H}, \mathrm{H}-\mathrm{a}$ from $\left.\mathrm{CH}_{2} \mathrm{Ph},{ }^{2} \mathrm{~J}_{\mathrm{a}, \mathrm{b}}=11.9, \alpha, \beta\right)$, 4.59, 4.55 ( $2 \mathrm{~d}$, part B of $\mathrm{AB}$ system, $1 \mathrm{H}, \mathrm{H}-\mathrm{b}$ from $\left.\mathrm{CH}_{2} \mathrm{Ph}, \alpha, \beta\right), 4.41-4.27$ (m, $2 \mathrm{H}, \mathrm{H}-$ $4, \alpha, \beta), 4.19-4.14$ (m, 2 H, H-2 $\alpha, \mathrm{H}-2 \beta) 4.11\left(\mathrm{dd}, 1 \mathrm{H}, \mathrm{H}-3 \alpha, J_{2,3(\alpha)}=4.1, J_{3,4}(\alpha)=5.7\right)$ $3.98\left(\mathrm{dd}, 1 \mathrm{H}, \mathrm{H}-3 \beta, J_{2,3}(\beta)=2.4, J_{3,4}(\beta)=5.6\right), 3.51-3.41\left(\mathrm{~m}, 3 \mathrm{H}, \mathrm{CH}_{2}-5 \beta, \mathrm{H}-5 \mathrm{a} \alpha, J_{5 \mathrm{a}, 5 \mathrm{~b}}\right.$ 
$\left.(\alpha)=14.3, J_{4,5 \mathrm{a}(\alpha)}=4.1\right), 3.36\left(\mathrm{dd}\right.$, part B of ABX system, $\left.1 \mathrm{H}, \mathrm{H}-5 \mathrm{~b} \alpha, J_{4,5 \mathrm{~b}(\alpha)}=6.4\right)$ ppm.

${ }^{13} \mathrm{C}$ NMR (MeOD, $\left.400 \mathrm{MHz}\right): \delta=163.1(\mathrm{Cq}, \mathrm{GN}), 139.3,139.1(\mathrm{Cq}, \mathrm{Ph}, \alpha, \beta), 129.5$

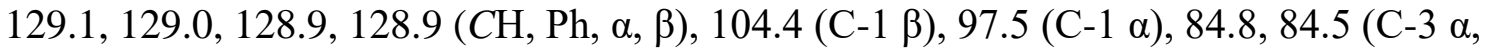
ק) $80.5,80.3$ (C-2 $\beta, \mathrm{C}-4 \beta), 77.3,77.0(\mathrm{C}-2 \alpha, \mathrm{C}-4 \alpha), 73.2,73.1\left(\mathrm{CH}_{2} \mathrm{Ph} \alpha, \beta\right), 43.8,43.0$ (C-5 $\alpha, \beta)$ ppm . HRMS: calcd for $\mathrm{C}_{13} \mathrm{H}_{19} \mathrm{~N}_{3} \mathrm{O}_{4}[\mathrm{M}+\mathrm{H}]+282.1448$, found 282.1445.

\subsection{Biological Assays}

\subsubsection{Cholinesterase Inhibition Assays}

A BMG Labtech Spectrostar Omega working in the slow kinetics mode and measuring the absorbance at a distinct wavelength of $\lambda=412 \mathrm{~nm}$ with center scanning was used for the enzymatic studies. In short: A mixture of a DTNB solution (125 $\mu \mathrm{L}, 3$ $\mathrm{mM}$ in $50 \mathrm{mM}$ Tris- $\mathrm{HCl}$ buffer, $\mathrm{pH} 8)$, enzyme solution $(25 \mu \mathrm{L}, 2 \mathrm{U} / \mathrm{mL})$ and compounds solutions ( $25 \mu \mathrm{L}, 3$ different concentrations and water as a blank) was incubated at $30{ }^{\circ} \mathrm{C}$ for $20 \mathrm{~min}$. The substrate $(25 \mu \mathrm{L},[\mathrm{ATChI}]=0.9375 \mathrm{mM}, 0.625 \mathrm{mM}, 0.325 \mathrm{mM}, 0.1875$ $\mathrm{mM}$ ) was added to start the enzymatic reaction. The absorbance data was recorded under a controlled temperature of $30{ }^{\circ} \mathrm{C}$ for $30 \mathrm{~min}$ at $1 \mathrm{~min}$ intervals at $\lambda=412 \mathrm{~nm}$. The relative inhibition was determined as the quotient of the slopes (compound divided by blank) of the linear ranges. The used substrate concentration was $0.625 \mathrm{mM}$.

The mode of inhibition as well as $K_{\mathrm{i}}$ and $K_{\mathrm{i}}^{\prime}$ values were determined using LineweaverBurk, Dixon and Cornish-Bowden plots.

\subsubsection{Antiproliferative Assays}

Human cancer cell lines were obtained from the European Collection of Authenticated Cell Cultures and were cultivated according to the provider's instructions. Briefly, MCF-7 and K562 cell linea were cultivated in DMEM medium supplemented with $10 \%$ fetal bovine serum. All media were supplemented with penicillin $(100 \mathrm{U} / \mathrm{mL})$ and streptomycin $(100 \mathrm{mg} / \mathrm{mL})$ and cell lines were cultivated at $37^{\circ} \mathrm{C}$ in $5 \% \mathrm{CO}_{2}$. For the viability assays, cells were seeded into 96-well plates in the appropriate densities and after $24 \mathrm{~h}$ preincubation period, were treated in triplicates with six different doses of each compound for 72 hours. After treatments, resazurin (Merck) solution was added for $4 \mathrm{~h}$, and fluorescence of resorufin corresponding to live cells was measured at $544 \mathrm{~nm} / 590 \mathrm{~nm}$ (excitation/emission) using a Fluoroskan Ascent microplate reader (Labsystems). The $\mathrm{GI}_{50}$ value, the drug concentration lethal to $50 \%$ of the cells, was calculated from the dose response curves that resulted from the assays. Imatinib and 5-fluorouracil were purchased from Merck. 
Acknowledgments: The authors thank 'Fundacão para a Ciência e Tecnologia' (FCT) for funding - grant number CEECIND/03881/2018, and the strategic projects UIDB/00100/2020, UIDP/00100/2020 (CQE), and UIDB/04046/2020, UIDP/04046/2020 (BioISI). Financial support from FCT/MCTES, Programa Operacional Regional de Lisboa (Lisboa 2020), Portugal 2020, FEDER/FN, and the European Union under Project No. 28455 (LISBOA-01-0145-FEDER-028455, PTDC/QUIQFI/28455/2017) is also acknowledged. Rafael S. Nunes is acknowledged for collaborating in the compounds' synthesis.

\section{References}

[1] Hannon C.L., Anslyn E.V. The Guanidinium Group: Its Biological Role and Synthetic Analogs. In: Dugas H., Schmidtchen F.P. (eds). Bioorganic Chemistry Frontiers, 1993, vol 3., 193-255, Springer, Berlin, Heidelberg. doi: 10.1007/978-3-64278110-0_6.

[2] Saczewski, F.; Balewski, Ł. Biological activities of guanidine compounds. Expert Opin. Ther. Pat. 2009, 19, 1417-1448. doi: 10.1517/13543770903216675.

[3] Berlinck, Roberto G. S.; Bertonha, A. F.; Takaki, M.; Rodriguez, J. P. G. The chemistry and biology of guanidine natural products. Nat. Prod. Rep. 2017, 34, 1264 1301. doi: 10.1039/c7np00037e.

[4] Blanco, F.; Kelly, B.; Alkorta, I.; Rozas, I.; Elguero, J. Cation- $\pi$ interactions: Complexes of guanidinium and simple aromatic systems. Chem. Phys. Lett. 2011, 511, 129-134. doi: 10.1016/j.cplett.2011.06.012.

[5] Sidoryk, K.; Świtalska, M.; Rózga, P.; Wietrzyk, J.; Bujak, I.; Żerek, B.; Kaczmarek, Ł.; Cybulski, M. An efficient synthesis of indolo[2,3-b]quinoline guanidine derivatives with their in vitro and in vivo study. Med. Chem. Res. 2017, 26, 3354-3366. doi: 10.1007/s00044-017-2028-1.

[6] Duca, G.; Aricu, A.; Kuchkova, K.; Secara, E.; Barba, A.; Dragalin, I.; Ungur, N.; Spengler, G. Synthesis, structural elucidation and biological evaluations of new guanidine-containing terpenoids as anticancer agents. Nat. Prod. Res., 2019, 33, 30523056. doi: 10.1080/14786419.2018.1516658.

[7] Li, C.; Lewis, M. R.; Gilbert, A. B.; Noel, M. D.; Scoville, D. H.; Allman, G. W.; Savage, P. B. Antimicrobial activities of amine- and guanidine-functionalized cholic acid derivatives. Antimicrob. Agents Chemother. 1999, 43, 1347-1349. doi: 10.1128/AAC.43.6.1347. 
[8] Mishra, A.; Batra, S. Thiourea and guanidine derivatives as antimalarial and antimicrobial agents. Curr. Top. Med. Chem. 2013, 13, 2011-2025. doi: 10.2174/15680266113139990126.

[9] Saeed, A.; Bosch, A.; Bettiol, M.; González, D. L. N.; Erben, M. F.; Lamberti, Y. Novel guanidine compound against multidrug-resistant cystic fibrosis-associated bacterial species. Molecules 2018, 23, 1158. doi:10.3390/molecules23051158.

[10] Pasero, C.; D’Agostino, I.; De Luca, F.; Zamperini, C.; Deodato, D.; Truglio, G. I.; Sannio, F.; Del Prete, R.; Ferraro, T.; Visaggio, D.; Mancini, A.; Guglielmi, M. B.; Visca, P.; Docquier, J.-D.; Botta, M. Alkyl-guanidine compounds as potent broadspectrum antibacterial agents: chemical library extension and biological characterization. J. Med. Chem. 2018, 61, 9162-9176. doi:

10.1021/acs.jmedchem.8b00619.

[11] Li, Z.; Meng,Y.; Xu, S.; Shen, W.; Meng, Z.; Wang, Z.; Ding, G.; Huang, W.; Xiao, W.; Xu, J. Discovery of acylguanidine oseltamivir carboxylate derivatives as potent neuraminidase inhibitors. Bioorg Med Chem. 2017, 25, 2772-2781. doi: 10.1016/j.bmc.2017.03.052.

[12] Hsu, P. H.; Chiu, D. C.; Wu, K. L.; Lee, P. S.; Jan, J. T.; Cheng, Y. S. E.; Tsai, K. C.; Cheng, T. J.; Fang, J. M. Acylguanidine derivatives of zanamivir and oseltamivir: potential orally available prodrugs against influenza viruses. Eur J Med Chem. 2018, 154, 314-323. doi: 10.1016/j.ejmech.2018.05.030.

[13] Cuzzocrea, S.; Zingarelli, B.; Hake, P.; Salzman, A. L.; Szabó, C.

Antiinflammatory effects of mercaptoethylguanidine, a combined inhibitor of nitric oxide synthase and peroxynitrite scavenger, in carrageenan-induced models of inflammation. Free Radic. Biol. Med. 1998, 24, 450-459. doi: 10.1016/s08915849(97)00280-3.

[14] Dambrova, M.; Zvejniece, L.; Skapare, E.; Vilskersts, R.; Svalbe, B.; Baumane, L.; Muceniece, R.; Liepinsh, E. The anti-inflammatory and antinociceptive effects of NF$\kappa \mathrm{B}$ inhibitory guanidine derivative ME10092. Int. Immunopharmacol. 2010, 10, 455460.doi: 10.1016/j.intimp.2010.01.006.

[15] Bi, X.; Lopez, C.; Bacchi, C.; Rattendi, D.; Woster, P. Novel alkylpolyaminoguanidines and alkylpolyaminobiguanides with potent antitrypanosomal activity. Bioorg. Med. Chem. Lett. 2006, 16, 3229-3232. doi:

10.1016/j.bmcl.2006.03.048. 
[16] Rozengart, E.V.; Basova, N. E. Guanidinium derivatives as reversible inhibitors of cholinesterases of various origins. Dokl. Biochem. Biophys. 2002, 384, 185-188. doi:10.1023/a:1016088601655.

[17] Rozengart, E.V.; Basova, N.E.; Zhorov, B.S.; Moralev, S. N.; Saakov,V. S.; Suvorov, A. A.; Khovanskikh A. E. Guanidine Derivatives: Conformation, Capability for Chelation, Study as Reversible Inhibitors of Cholinesterases of Different Origin. $J$. Evol. Biochem. Physiol. 2003, 39, 393-404. doi: 10.1023/B:JOEY.0000010235.00798.98.

[18] Gerritz, S. W.; Zhai, W.; Shi,S.; Zhu, S.; Toyn, J. H.; Meredith, J. E., Jr.; Iben; L. G.; Burton,C. R.; Albright, C. F.; Good, A. C.; Tebben, A. J.; Muckelbauer, J. K.; Camac, D. M.; Metzler, W.; Cook, L. S.; Padmanabha, R.; Lentz, K. A.; Sofia, M. J.; Poss, M. A.; Macor, J. E.; Thompson, III, L. A. Acyl guanidine inhibitors of $\beta$-secretase (BACE-1): optimization of a micromolar hit to a nanomolar lead via iterative solid- and solution-phase library synthesis. J. Med. Chem. 2012, 55, 9208-9223. doi: 10.1021/jm300931y.

[19] Patwardhan, N. N.; Morris, E. A.; Kharel, Y.; Raje, M. R.; Gao, M.; Tomsig, J. L.; Lynch, K. R.; Santos, W. L. Structure-Activity Relationship Studies and in Vivo Activity of Guanidine-Based Sphingosine Kinase Inhibitors: Discovery of SphK1- and SphK2-Selective Inhibitors. J. Med. Chem. 2015, 58, 1879-1899.

doi:10.1021/jm501760d.

[20] Wang, Y.-W.; He, S.-J.; Feng, X.; Cheng, J.; Luo, Y.-T.; Tian, L.; Huang, Q. Metformin: a review of its potential indications. Drug Des. Devel. Ther. 2017, 11, 2421-2429. doi: 10.2147/DDDT.S141675.

[21] Tse, E. G.; Korsik, M.; Todd, M. H. The past, present and future of anti-malarial medicines. Malar. J. 2019, 18, 93. doi: 10.1186/s12936-019-2724-z.

[22] Wang, S.; Zhang, Q.; Zhao, Y.; Sun, J.; Kang, W.; Wang, F.; Pan, H.; Tang, G.; $\mathrm{Yu}, \mathrm{B}$. The miharamycins and amipurimycin: their structural revision and the total synthesis of the latter. Angew. Chem. Int. Ed. 2019, 58, $10558-10562$.

[23] Marcelo, F.; Jiménez-Barbero, J.; Marrot, J.; Rauter,A. P.; Sinaÿ, P.; Blériot, Y. Stereochemical Assignment and First Synthesis of the Core of Miharamycin Antibiotics. Chem. Eur. J. 2008, 14, 10066-10073. doi: 10.1002/chem.200801826.

[24] Ren, H.; An, H.; Hatala, P. J.; Stevens, W. C., Jr.; Tao, J.; He, B. Versatile synthesis and biological evaluation of novel 3'-fluorinated purine nucleosides. Beilstein J. Org. Chem. 2015, 11, 2509-2520. doi:10.3762/bjoc.11.272. 
[25] Melroy. J.; Nair, V. The antiviral activity, mechanism of action, clinical significance and resistance of abacavir in the treatment of pediatric AIDS. Curr Pharm Des. 2005, 11, 3847-3852. doi:10.2174/138161205774580642.

[26] Nicolaou, K. C.; Vourloumis, D.; Totokotsopoulos, S.; Papakyriakou, A.; Karsunky, H.; Fernando, H.; Gavrilyuk, J.; Webb, D.; Stepan, A.F. Synthesis and biopharmaceutical evaluation of imatinib analogues featuring unusual structural motifs. ChemMedChem 2016, 11, 31 - 37. doi: 10.1002/cmdc.201500510.

[27] Shelton, J.; Lu, X.; Hollenbaugh, J.A.; Cho, J.H.; Amblard, F.; Schinazi, R.F. Metabolism, biochemical actions, and chemical synthesis of anticancer nucleosides, nucleotides, and base analogs. Chem. Rev. 2016, 116, 14379-14455. doi:

10.1021/acs.chemrev.6b00209.

[28] Seley-Radtke, K.L.; Yates, M. K. The evolution of nucleoside analogue antivirals: A review for chemists and non-chemists. Part 1: Early structural modifications to the nucleoside scaffold. Antiviral Res. 2018, 154, 66-86. doi:

10.1016/j.antiviral.2018.04.004.

[29] Delaware, D.L.; Sharma, M.S.; Iyengar, B. S.; Remers, W.A. Aminoglycoside antibiotics. 7. Dihydrostreptomycin analogues. J. Antibiot. 1986, 39, 251-258. doi: 10.7164/antibiotics.39.251.

[30] Colman, P. M. Zanamivir: an influenza virus neuraminidase inhibitor, Expert Rev. Anti Infect. Ther. 2005, 3, 191-199, doi: 10.1586/14787210.3.2.191.

[31] Jeong, J.-H.; Murray, B. W.; Takayama, S.; Wong, C.-H. Cyclic guanidino-sugars with low $\mathrm{pKa}$ as transition-state analog inhibitors of glycosidases: neutral instead of charged species are the active forms. J. Am. Chem. Soc. 1996, 118, 18, 4227-4234. doi: $10.1021 /$ ja951602z.

[32] Le Merrer, Y.; Gauzy, L.; Gravier-Pelletier, C.; Depezay, J.-C. Synthesis of C2symmetric guanidino-sugars as potent inhibitors of glycosidases. Bioorg. Med. Chem. 2000, 8, 307-320. doi: 10.1016/S0968-0896(99)00294-1.

[33] Aguilar, M.; Díaz-Pérez, P.; García-Moreno, M.I.; Mellet, C.O.; García Fernández, J. M. Synthesis and biological evaluation of guanidine-type iminosugars. J. Org. Chem. 2008, 73, 1995-1998. doi:10.1021/jo702374f. 
[34] Merino-Montiel, P.; López, O.; Fernández-Bolaños, J. G. Unprecedented spiroannelated sugar isoureas, guanidines and amidines as new families of glycosidase inhibitors, RSC Adv., 2012, 2, 11326-11335. Doi: 10.1039/C2RA21561F.

[35] Sevšek, A.; Šrot, L.; Rihter, J.; Čelan, M.; van Ufford, L. Q.; Moret, E. E.; Martin, N. I.; Pieters, R. J. N-Guanidino derivatives of 1,5-dideoxy-1,5-imino-D-xylitol are potent, selective, and stable inhibitors of $\beta$-glucocerebrosidase. ChemMedChem 2017, 12, 483-486. doi: 10.1002/cmdc.201700050.

[36] Chen, H.-M.; Zhao, Y.-W.; Cao, L.-H. Synthesis and bioactivity of $N$-glycosyl- $N$ '(4-arylthiazol-2-yl) aminoguanidines, J. Chin. Chem. Soc., 2010, 57, 1085-1090. doi: $10.1002 /$ jccs.201000153.

[37] Srivastava, A.; Loganathan, D. Synthesis of guanidino sugar conjugates as GlcßArg analogs. Glycoconj J. 2013, 30, 769-780. doi:10.1007/s10719-013-9480-z. [38] Jiménez Blanco, J. L.; Bootello, P.; Benito, J. M.; Ortiz Mellet, C.; Garcia Fernández, J. M. Urea-, thiourea-, and guanidine-linked glycooligomers as phosphate binders in water, J. Org. Chem. 2006, 71, 5136-5143. doi: 10.1021/jo060360q.

[39] Barawkar, D. A.; Bruice, T. C. Synthesis, biophysical properties, and nuclease resistance properties of mixed backbone oligodeoxynucleotides containing cationic internucleoside guanidinium linkages: Deoxynucleic Guanidine/DNA Chimeras. Proc. Natl Acad. Sci. USA 1998, 95, 11047-11052. DOI: 10.1073/pnas.95.19.11047.

[40] Kojima, N.; Szabo, I. E.; Bruice, T. C. Synthesis of ribonucleic guanidine: replacement of the negative phosphodiester linkages of RNA with positive guanidinium linkages. Tetrahedron 2002, 58, 867-879. doi: 10.1016/S00404020(01)01185-1.

[41] Park, M.; Canzio, D.; Bruice, T. C. Incorporation of positively charged ribonucleic guanidine linkages into oligodeoxyribonucleotides: development of potent antisense agents. Bioorg. Med. Chem. Lett. 2008, 18, 2377-2384. doi:

10.1016/j.bmcl.2008.02.063.

[42] Kojima, N.; Shrestha, A. R.; Akisawa, T.; Piao, H.; Kizawa, H.; Ohmiya, Y.; Kurita, R. Development of gapmer antisense oligonucleotide with deoxyribonucleic guanidine (DNG) modifications. Nucleosides Nucleotides Nucleic Acids 2019, 39, 258269. doi: 10.1080/15257770.2019.1668563.

[43] Sharma, K. Cholinesterase inhibitors as Alzheimer's therapeutics. Mol. Med. Rep. 2019, 20, 1479-1487. doi: 10.3892/mmr.2019.10374. 
[44] Darras, F.H.; Kling, B; Sawatzky, E.; Heilmann, J.; Decker. M. Cyclic acyl guanidines bearing carbamate moieties allow potent and dirigible cholinesterase inhibition of either acetyl- or butyrylcholinesterase. Bioorg. Med. Chem. 2014, 22, 5020-5034. doi: 10.1016/j.bmc.2014.06.010.

[45] Batista, D.; Schwarz, S.; Loesche, A.; Csuk, R.; Costa, P. J.; Oliveira, M. C.; Xavier, N. M. Synthesis of glucopyranos-6'-yl purine and pyrimidine isonucleosides as potential cholinesterase inhibitors. Access to pyrimidine-linked pseudodisaccharides through Mitsunobu reaction. Pure Appl. Chem. 2016, 88, 363-379. doi: 10.1515/pac2016-0102.

[46] Xavier, N. M.; Lucas, S. D.; Jorda, R.; Schwarz, S.; Loesche, A.; Csuk, R.; Oliveira, Synthesis and evaluation of the biological profile of novel analogs of nucleosides and of potential mimetics of sugar phosphates and nucleotides. Synlett, 2015, 26, 2663-2672. doi: 10.1055/s-0035-1560591.

[47] Fortuna, A.; Costa, P. J.; Piedade, M. F. M.; Oliveira, M. C.; Xavier, N. M. Synthesis of triazole-containing furanosyl nucleoside analogs and their phosphate, phosphoramidate or phoshonate derivatives as potential sugar diphosphate or nucleotide mimetics. ChemPlusChem 2020, 85, 1676-1691. DOI: 10.1002/cplu.202000424.

[48] Xavier, N. M.; Goncalves-Pereira, R.; Jorda, R.; Hendrychová, D.; Oliveira, M. C. Novel dodecyl-containing azido and glucuronamide-based nucleosides exhibiting anticancer potential. Pure Appl. Chem. 2019, 91, 1085-1105. doi: 10.1515/pac-20190106.

[49] Gonçalves-Pereira, R.; Pereira, M. P.; Serra, S. G.; Loesche, A.; Csuk, R.; Silvestre, S.; Costa, P. J.; Oliveira, M. C.; Xavier, N. M. Furanosyl nucleoside analogues embodying triazole or theobromine units as potential lead molecules for Alzheimer's disease. Eur. J. Org. Chem. 2018, 2018, 2667-2681. doi:

10.1002/ejoc. 201800245.

[50] Tulshian, D. B.; Fundes, A. F.; Czarniecki, M. Versatile synthesis of dihydroxy $\gamma$ and $\delta$-amino acids from carbohydrates. Bioorg. Med. Chem. Lett. 1992, 2, 515-518. doi: 10.1016/S0960-894X(01)81188-4.

[51] Santana, A.; Francisco, C. G.; Suarez, E.; Gonzalez, C. C. Synthesis of guanidines from azides: a general and straightforward methodology in carbohydrate chemistry. $J$. Org. Chem. 2010, 75, 5371-5374. doi: 10.1021/jo100876r. 
[52] Santana, A. G.; González, C. C. Tandem Radical Fragmentation/Cyclization of Guanidinylated Monosaccharides Grants Access to Medium-Sized Polyhydroxylated Heterocycles. Org. Lett. 2020, 22, 21, 8492-8495. doi: 10.1021/acs.orglett.0c03091.

[53] Girard, C.; Önen, E.; Aufort, M.; Beauvire, S.; Samson, E.; Herscovici, J. Reusable Polymer-Supported Catalyst for the [3+2] Huisgen Cycloaddition in Automation Protocols. Org. Lett. 2006, 8, 1689-1692.

[54] Bock, V. D.; Perciaccante, R.; Jansen, T. P.; Hiemstra, H.; van Maarseveen, J. H. Click Chemistry as a Route to Cyclic Tetrapeptide Analogues: Synthesis of cyclo-[Pro-

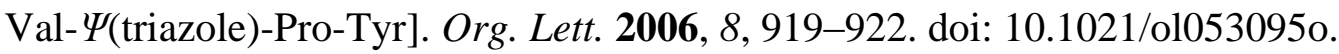

[55] Tanaka, K.; Kageyama, C.; Fukase, K. Acceleration of $\mathrm{Cu}(\mathrm{I})$-mediated Huisgen 1,3-dipolar cycloaddition by histidine derivatives Tetrahedron Lett. 2007, 48, 64756479. doi:10.1016/j.tetlet.2007.07.055.

[56] Smith, N. W.; Polenz, B. P.; Johnson, S. B.; Dzyuba, S. V. Base and concentration effects on the product distribution in copper-promoted alkyne-azide cycloaddition: additive-free route to 5-iodo-triazoles. Tetrahedron Lett. 2010, 51, 550-553. doi:10.1016/j.tetlet.2009.11.089.

[57] Lundt, B.F.; Johansen, N. L.; Vølund, A.; Markussen, J. Removal of t-butyl and tbutoxycarbonyl protecting groups with trifluoroacetic acid. Mechanisms, biproduct formation and evaluation of scavengers. Int. J. Pept. Protein Res. 1978, 12(5), 258-268. doi: 10.1111/j.1399-3011.1978.tb02896.x.

[58] Mehta, A.; Jaouhari, R.; Benson, T. J.; Douglas, K. T. Improved efficiency and selectivity in peptide synthesis: use of triethylsilane as a carbocation scavenger in deprotection of $t$-butyl esters and $t$-butoxycarbonyl-protected sites, Tetrahedron Lett. 1992, 33, 5441-5444. doi: 10.1016/S0040-4039(00)79116-7.

[59] Wessel, H. P. Syntheses of 6-guanidino-hexoses and 5-guanidinopentoses, $J$. Carbohydr. Chem. 1993, 12, 1173-1186. doi: 10.1080/07328309308020126.

[60] Harris, R. K.; Becker, E. D.; Cabral de Menezes, S. M.: Goodfellow, R.; Granger, P. NMR Nomenclature. Nuclear spin properties and conventions for chemical shifts. Pure Appl. Chem. 2001, 73, 1795-1818. doi: 10.1351/pac200173111795. 